Egyptian Poultry Science Journal

http://www.epsaegypt.com

ISSN: 1110-5623 (Print) - 2090-0570 (On line)

\title{
EFFECT OF SEASON AND DIETARY L-CARNITINE SUPPLEMENTATION ON PRODUCTIVE AND REPRODUCTIVE PERFORMANCE OF LOCAL DUCK BREEDS
}

\author{
A. L. Awad ; H. N. Fahim and M.M. Beshara
}

Anim. Prod. Res. Institute, Agric. Res. Center, Ministry of Agric. Dokki, Giza

\author{
Received: 17/12/2015 Accepted: 10/01/2016
}

\begin{abstract}
The main objective of this study was to investigate the effect of season and dietary L-carnitine (LC) supplementation on productive and reproductive performance of local duck breeds. A total number of 285 Domyati ducks (225 ducks and 60 drakes), 25-wkold were taken for each experimental season (winter and summer). Ducks were weighed, divided into five experimental groups and fed diets supplemented with different LC levels $(0,150,300,450$ and $600 \mathrm{mg} / \mathrm{kg}$ diet $)$ during the experimental period (25-41 weeks of age) for each season.

Results indicated that some studied productive traits such as egg number (EN), egg mass (EM) and feed consumption (FC) were significantly decreased for ducks reared in summer than those reared in winter season. Moreover, dietary LC supplementation resulted in a significant improvement in EN, EM, FC and feed conversion ratio as compared to the control group during the period of 25-41 weeks of age. Reproductive traits such as egg fertility and hatchability (\%) as well as semen quality parameters ( ejaculate volume, sperms concentration and mass motility) were significantly decreased for ducks reared in summer season than winter, while these parameters were significantly improved by dietary LC supplementation as compared to the control. Blood hemoglobin (HB) and lymphocytes (L) cells $(\%)$ were significantly decreased, while white blood cells (WBC) and heterophils (H) cells $(\%)$ were significantly increased for ducks reared in summer season than winter. However, supplementing LC with 300 up to $600 \mathrm{mg} / \mathrm{kg}$ diet significantly increased $\mathrm{HB}$ and L cells (\%), while it decreased $\mathrm{H}$ cells $(\%)$ and $\mathrm{H} / \mathrm{L}$ ratio than the control. Serum triglycerides, total cholesterol levels and liver enzyme activities (ALT\&AST) were significantly higher for ducks reared in summer than winter season, whereas, these parameters were significantly decreased by dietary LC supplementation except for serum triglycerides. All nutrients digestibility coefficient, total digestibility of nutrients and metabolizable energy (ME $\mathrm{kcal} / \mathrm{kg}$ ) were significantly decreased for ducks reared in summer than winter season except for nitrogen free extract, whereas, all pervious parameters were improved with or without significant effect by dietary LC supplementation. Feeding economic efficiency and net return were significantly improved for ducks reared in summer season and dietary LC supplementation as compared to the control.
\end{abstract}

Key Words: L- carnitine, Ducks, Productive and Reproductive Performance, Season.

Corresponding author: awad1512@yahoo.com 
These results indicate that summer season had negative effect on productive and reproductive performance, but dietary LC supplementation with 150 up to $450 \mathrm{mg} / \mathrm{kg}$ for Domyati ducks in summer season could be used to maximize and improve productive and reproductive performance, nutrients digestibility coefficients and economic efficiency.

\section{INTRODUCTION}

Poultry industry has developed in several areas such as nutrition, genetics, and management to maximize the efficiency of growth performance, egg and meat yield. The development of ducks sector in Egypt suffers many constraints hindering its overall growth and laying production, especially local duck breeds. Domyati ducks is one of the local duck breeds in Egypt and they reared for a diverse production situations such as meat and egg production (Awad et al., 2011). Stress occurs when an animal experiences changes in the environment that stimulate body responses aimed at re-establishing homeostatic conditions (Mumma et al., 2006). Environmental stress include abiotic factors (such as climate, temperature and chemical components) and biotic factors (such as competition, nutrition and various forms of infectious diseases), which can act independently, but often act synergistically (Bijlsma and Loeschcke, 2005). Seasonal variation is one of the major non-genetic factors affecting poultry production, high environmental temperature commonly called heat stress, adversely affected egg production performance of commercial layers (Oguntunji and Salako, 2012), fertility and hatchability (Obidi et al., 2008) of breeders. The thermogenic mechanisms based in part on the increased capacity for mitochondrial substrate oxidation in different tissues are associated with enhanced heat production to attain homeothermy and acquire tolerance to acute cold exposure (Mujahid, 2010).

L-carnitine is a natural, vitamin-like aminoacid, synthesized within the body from lysine and methionine (Vaz and Wanders, 2002). Although L-carnitine is synthesized in the body, conditions such as stress, disease, and physical strain may result in Lcarnitine deficiency (Neuman et al., 2002). According to Harmeyer and Baumgartner (1999), the body can not produce enough Lcarnitine to fully cover its own needs. Moreover, L-carnitine is used in poultry for multi-functional purposes that include promoting growth, strengthening the immune system and as an antioxidant (Adabi et al., 2011). Poultry diets are composed mainly of maize and soya bean and plant products which contained a low Lcarnitine level, as a result of the ban on the use of animal-based meal in poultry feeding, consequently resulted in more L-carnitine deficiency in poultry diet. Dietary supplementing L-carnitine or precursors and cofactors may be required when metabolic rate and energy demands are increased in poultry breeding in order to improve productive or reproductive performance and stress resistance (Thiemel and Jelínek, 2004). Some studies reported that supplementing L-carnitine $(50-150 \mathrm{mg} / \mathrm{kg}$ diet) improve hatchability, egg production, egg weight and mass in poultry (Nofal et al. , 2006), increase sperm concentration and decrease lipid peroxidation of spermatozoa in roosters (Zhai et al., 2008) and improve semen volume, sperm motility and viability and spermatozoa count in ostrich (Adabi et al., 2011). Therefore, the aim of this study was to investigate the effects of season and dietary L-carnitine supplementation on productive and reproductive performance of local duck breeds (Domyati).

\section{MATERIALS AND METHODS}

This study was carried out at El - Serw Water Fowl Research Station, Animal Production Research Institute, Agricultural Research Center, Ministry of Agriculture, Egypt. This study was conducted through 
two experimental periods, the first period was carried in winter season (2014-2015), while the second period was carried in summer season (2015). Two hundred and eighty five Domyati ducks (225 ducks and 60 drakes), 25-wks-old were taken for each experimental period (season). Birds for each experimental period were weighed and randomly distributed into five experimental groups, each contained 57 birds (45 ducks and 12 drakes), then divided into equal three replicates (15 ducks and 4 drakes). Ducks of each replicate were housed as 2.3 ducks $/ \mathrm{m}^{2}$ in a house with windows and received additional artificial light to provide $16 \mathrm{~h}$ light and $8 \mathrm{~h}$ dark daily. Throughout the experimental period, feed and fresh water were available all the time. Five graded levels of L- carnitine (LC) 0, 150, 300, 450 and $600 \mathrm{mg} / \mathrm{kg}$ diet were supplemented to the basal layer diet and fed to the five experimental groups. The composition and calculated analysis of the basal experimental diet are shown in Table 1.

\section{Data collection and estimated parameters: \\ Productive performance:-}

Egg number (EN), egg mass (EM) and feed consumption (FC) were recorded for each replicate then averaged and expressed per duck / 4 wks through the experimental intervals : 25-29, 29-33, 33$37,37-41$ and the overall experimental period (25-41 wks of age) for each experimental season. Feed conversion ratio (FCR) was calculated through the same periods ( $\mathrm{g}$ feed / g eggs). Mortality number was recorded weekly during the overall experimental period $(25-41 \mathrm{wks}$ of age), then ducks viability (\%) was calculated through the whole experimental period.

\section{Reproductive performance:-}

1. Semen quality traits: Three drakes were used from each treatment on the basis of a positive reaction to dorsoabdominal massage for artificial collection of semen. Semen was collected weekly during the experimental period, then ejaculate volume, sperms motility and concentration were determined for each drake.

2. Hatching traits and ducklings quality: Hatching traits were measured by collecting eggs for incubation through the experimental period. Fertile eggs and early embryonic mortality were counted at the $10^{\text {th }}$ day of incubation. Then, hatched ducklings and late embryonic mortality (un-hatched eggs with live or dead embryos and dead hatched ducklings) were counted at the end of incubation period. Then, hatchability and embryonic mortality percentages were calculated. Also, hatched ducklings were weighed and graded according to Tona et al. (2004), which ducklings were classified as a first-grade when they were clean, dry, free of deformities and have bright eyes, while the rest of ducklings were classified as second-grade.

\section{Hematological and serum biochemical parameters:}

1. At week 33 of age, blood samples were collected in vial tubes containing EDTA as anticoagulant from three ducks per treatment to determine some hematological traits such as hemoglobin concentration and total leukocytes counts. Total white blood cells were counted by haemocytometer, while heterophils $(\mathrm{H})$ and lymphocytes (L) were counted in blood smears by using Wright's stain technique, then $\mathrm{H}$ : $\mathrm{L}$ ratios were calculated.

2. At week 38 of age, blood samples were taken from the wing vein from 3 ducks per treatment without anticoagulant and kept at room temperature for one hour to clot. Tubes were centrifuged at $3000 \mathrm{rpm}$ for 15 minutes to separate clear serum, then blood serum was used to determine serum total protein, triglycerides, total cholesterol and liver enzymes activities (AST and ALT) by using commercial kits. 


\section{Nutrients digestibility coefficient:}

At week 39 of age, three drakes from each treatment were taken to evaluate the nutrients digestibility coefficient. Drakes were fed on their experimental diets for seven days as a preliminary period, followed by three days collection period, where excreta were quantitatively collected. Simultaneously, records of daily feed consumption for each drake were maintained. The daily excreta was voided from each drake in each treatment, pooled and thoroughly mixed. Then, representative excreta samples were taken and dried immediately for chemical analysis (AOAC, 1995). Digestion coefficients were determined for dry and organic matter (DM \& OM), crude protein $(\mathrm{CP})$, crude fiber $(\mathrm{CF})$, ether extract (EE) and nitrogen free extract (NFE) as well as total digestible nutrient (TDN) and metabolizable energy were calculated.

Economic efficiency and net return: Data were calculated based on the prices of L-carnitine tartrate $68.7 \%$ (150 LE/ one $\mathrm{kg}$ ) and one egg (1.0 LE) prevailing during year 2015 .

Statistical analysis: Data obtained were statistically analyzed using the general linear model of SAS (2004). In this study, a factorial design $(2 \times 5)$ was used, considering the season and dietary LC supplementation as the main effects, as follows:

Yijk $=\mu+\mathrm{Ti}+\mathrm{Rj}+(\mathrm{TR}) \mathrm{ij}+$ eijk where : Yijk $=$ an observation; $\mu=$ Overall mean; $\mathrm{T}=$ Effect of season; $\mathrm{i}=(1$ and 2$)$;

$\mathrm{R}=$ Effect of LC supplementation level; $\mathrm{j}=(1,2$ and 5$)$;

$\mathrm{TR}=$ Effect of interaction between season and LC supplementation level; and eijk = Random error. Significant differences among treatments means were tested by Duncan's multiple range test (Duncan, 1955).

\section{RESULTS AND DISCUSSION}

\section{Productive performance traits:-}

Egg number and mass:

Significant differences were observed among the experimental groups in egg number and mass (EN \& EM) per duck through all experimental periods due to the season and dietary LC supplementation (Table 2). Egg number was significantly decreased by $6.44 \%$, while EM was significantly decreased by $10.71 \%$ for ducks reared in summer than those reared in winter season during the overall experimental period (25-41 wks of age). The decrease of egg production (EN or EM) through summer season may be due to heat stress which may cause a hormonal distortion equilibrium associated with ovarian activities and reduce feed intake as well as decrease antioxidant capacity which will simultaneously prevent birds from intake of necessary nutrients needed for body maintenance and egg production (Ma et al., 2014). On the other hand, dietary LC supplementation resulted in a significant improvement in EN by about $8.59,10.07,8.10$ and $7.46 \%$, while EM was significantly heavier by $12.69,12.95,11.70$ and $11.55 \%$ for ducks fed diet supplemented with 150, 300, 450 and 600 $\mathrm{mg} \mathrm{LC} / \mathrm{kg}$, respectively than those fed the control diet during the overall experimental period (25-41 wks of age). The interaction between season and dietary LC supplementation had significant effects on EN and EM throughout all experimental periods except for 25-29 and 29-33 wks of age. Ducks fed diet supplemented with 150 $\mathrm{mg} \mathrm{LC} / \mathrm{kg}$ in winter season recorded the best EN (82.08) and EM (5679.1 g), while the lowest value of EN (69.68) and EM (4371.7 g) was occurred for ducks fed the control diet in summer season during the overall experimental period. The significant improvement of egg production (EN or EM) may be due to dietary LC supplementation plays a major role of increase FSH and LH hormones concentration by increasing the concentrations of estrogen and progesterone 
hormones which they work together on growth and maturity of ovarian small follicles and accelerate the process of ovulation, or LC is a generator of many amino acids, which ultimately lead to an increase in the proportion of egg production and egg weight by improving the formations and secretion of albumin layers by stimulating lipoprotein precursor's synthesis in the liver and then deposited into oviduct (Al - Daraji and Tahir, 2013). These results are in agreement with those obtained by Al-Hayani (2012) who reported that supplementing $300 \mathrm{mg} \mathrm{LC} / \mathrm{kg}$ diet improved productive traits such as egg production and egg weigh compared with the control group of guinea fowl. Also, ALDaraji and Tahir (2013) reported that dietary LC supplementation $(150 \mathrm{mg} / \mathrm{kg})$ resulted in a significant improvement in accumulative egg number and weight for local ducks. However, Richter et al. (1998) showed that dietary supplementation of LC (50 up to $500 \mathrm{mg} / \mathrm{kg}$ ) did not influence egg number and mass of Tetra SL laying hens. Also, Nofal et al. (2006) showed that egg number of Gimmizah lying hens were not significantly affected by LC supplementation ( 25 up to $125 \mathrm{mg} / \mathrm{kg}$ ) as compared with control group.

\section{Feed consumption:}

Feed consumption (FC) was significantly affected due to season, dietary LC supplementation and their interaction through some experimental periods (Table 3). Feed consumption was significantly decreased by $13.09 \%$ for ducks reared in summer than those reared in winter season during the period of 25-41 wks of age. The lower feed consumption during summer season may probably be one of the physiological responses employed by the bird to reduce increased body heat load associated with feed intake most especially when environmental temperature is elevated (Simon, 2003). This result supports the finding of Ma et al. (2014) who reported that feed consumption was significantly decreased by $11.90 \%$ for ducks exposed to high temperature $34 \circ \mathrm{C}$ than those exposed to 23 - C. Moreover, dietary LC supplementation had no significant effect on FC during all experimental periods except for the first period (25-29 wks) and the overall experimental period (25-41 wks of age). Ducks fed diet supplemented with 450 and $600 \mathrm{mg} \mathrm{LC} / \mathrm{kg}$ significantly consumed less amount of feed by about 3.28 and $2.78 \%$, respectively than those fed control diet during the overall experimental period. The interaction between season and dietary LC supplementation had significant effects on FC during all experimental periods except for 25-29 wks of age. Ducks fed the control diet in winter season consumed the highest amount of feed $(19.93 \mathrm{~kg})$ followed by those fed $150 \mathrm{mg} \mathrm{LC} / \mathrm{kg}$ diet $(19.18 \mathrm{~kg})$, while ducks fed the control diet in summer season consumed the lowest amount of feed $(16.223 \mathrm{~kg})$ during the period of $25-41 \mathrm{wks}$ of age. These results may be due to ducks are able to compensate their feed intake according to their productivity and energy density of the diet. These results are in agreement with those obtained by Yalcin et al. (2005) who reported that addition of LC resulted in a significant $(\mathrm{P} \leq 0.05)$ lower average feed intake. However, Parizadian et al. (2011) reported that dietary LC supplementation had no significant effect on feed intake for quail hens.

\section{Feed conversion ratio:-}

The effects of season and dietary LC supplementation and their interaction on feed conversion ratio (FCR) are presented in Table 3. Ducks reared in summer season had significantly better value of FCR than those reared in winter season during all the experimental period except for 25-29 and $37-41$ wks of age. Feed conversion ratio was significantly decreased for ducks reared under winter than those reared under summer season during the overall experimental period by $2.82 \%$. These results may be due to ducks had consumed more amount of feed during winter season to 
supply energy requirements for maintaining their life and for eggs production. Moreover, Supplementing different LC levels to the diet had significant effects on FCR during all experimental periods (Table 3). Ducks fed diet supplemented with different LC levels had the best FCR being 12.31- 13.33 $\%$ more than those fed the control diet during 25-41 wks of age. Feed conversion ratio was not significantly affected due to the interaction between season and dietary LC supplementation during the experimental periods except for 25-29 and 25-41 wks of age only. The worst FCR values were occurred for ducks fed the control diet at summer and winter conditions, whereas, the best FCR value was occurred for ducks fed 150 and $300 \mathrm{mg}$ $\mathrm{LC} / \mathrm{kg}$ diet at summer conditions during the overall experimental period. This result may be due to the increase of egg number and mass as well as a decrease in feed consumption per duck. These results are in agreement with those obtained by Behrouz et al. (2010) who concluded that supplementing LC $(200 \mathrm{mg} / \mathrm{kg}$ diet $)$ significantly improved $(\mathrm{P} \leq 0.05)$ feed conversion ratio of laying hens during 50 70 wks of age. Also, Al-Hayani (2012) reported that supplementing $300 \mathrm{mg} \mathrm{LC} / \mathrm{kg}$ diet of guinea fowl improved feed conversion ratio.

\section{Reproductive performance traits:- Semen quality parameters:-}

All studied semen quality parameters for Domyati drakes were significantly affected due to the season except of live and dead sperms percentages (Table 4). The values of ejaculate volume, sperm concentration and mass motility were significantly $(\mathrm{P} \leq 0.05)$ lower, while abnormal sperms (\%) was significantly higher for drakes reared in summer than those reared in winter season. These results may be due to heat stress in summer season which suppresses reproductive capacity of males as a result of a decrease in spermatogenesis activity seminiferous epithelial cells, which is manifested in decreased semen quality and quantity with time (Obidi et al., 2008). On the other hand, all studied semen quality parameters for Domyati drakes were significantly affected due to dietary L-carnitine (LC) supplementation (Table 4). Ejaculate volume was significantly increased by $12.50,21.87$ and $12.50 \%$ for drakes fed diet supplemented with 300,450 and $600 \mathrm{mg}$ $\mathrm{LC} / \mathrm{kg}$, respectively than those fed the control diet. Spermatozoa concentration was significantly higher by $23.00-29.58 \%$ for drakes fed diets supplemented with different LC levels (150 up to $600 \mathrm{mg} / \mathrm{kg}$ ) than those fed the control diet. Live sperms $(\%)$ was significantly increased, while dead sperms (\%) was significantly decreased by feeding different LC diets than the control. Abnormal sperms (\%) was significantly decreased by 25.13 and $26.25 \%$ for drakes fed diet supplemented with 450 and $600 \mathrm{mg}$ $\mathrm{LC} / \mathrm{kg}$ than the control, while, it was insignificantly decreased by 5.57 and $14.17 \%$ for drakes fed 150 and $300 \mathrm{mg}$ LC/kg diet, respectively. Also, sperms mass motility (\%) was significantly improved by supplementing LC with 300 up to $600 \mathrm{mg} / \mathrm{kg}$ diet than the control. The interaction between the season and dietary LC supplementation had no significant effects on all studied semen quality parameters except of sperms mass motility and abnormal (\%). The worst abnormal sperms and mass motility values were recorded for drakes fed all experimental diets in summer and the control and $150 \mathrm{mg} \mathrm{LC} / \mathrm{kg}$ diet in winter, whereas, the best values were recorded for drakes fed 450 and $600 \mathrm{mg}$ $\mathrm{LC} / \mathrm{kg}$ diet at winter conditions. The significant improvement in semen quality traits (sperms concentration, live sperms and mass motility or decreasing abnormal and dead sperms ) may be due to the role of Lcarnitine in the oxidation of long-chain fatty acids, which improves spermatogenesis and reduce damage of spermatozoa membranes within the seminiferous tubules of the testis (Neuman et al., 2002). In addition, L- 
carnitine has a pivotal role in sperm movement because it's an energy substrate and it's a powerful antioxidant which prevent the formation of free radicals in the semen which reduce sperm motility, vitality and prevent the reaction of the acrosome with the membrane which reduce the lifespan of the sperm (Al-Daraji and Taher, 2014b). These results are in agreement with those obtained by Baumgartner (2003) who reported that dietary supplementing with 250 up to 500 $\mathrm{mg} \mathrm{LC} / \mathrm{kg}$ resulted in a significant improvement in sperm count and quality for roosters. Also, Zhai et al. (2008) reported that LC supplementation to the diet increased sperm concentration. Supplementing dietary L-carnitine (250 or $500 \mathrm{mg} / \mathrm{kg}$ ) had significantly increased sperm viability and decreased multinucleated giant cells per testes in mature male of Japanese quails (Sarica et al., 2007). Similarly, Al-Daraji and Taher (2014b) found that dietary LC supplementation $(150 \mathrm{mg} / \mathrm{kg})$ significantly increased ejaculate volume, sperms concentration and sperms viability and mass motility, while dead and abnormal sperms (\%) were significantly decreased for Iraqi drakes.

\section{Hatching traits:-}

Data of Table 5 show the effect of season, dietary LC supplementation and their interaction on hatching traits and ducklings quality. Fertility and hatchability of fertile eggs (\%) were significantly decreased, while early, late and total embryonic mortality (\%) were significantly increased for ducks reared in summer than those reared in winter season. Fertility and hatchability $(\%)$ were significantly decreased by 2.87 and $14.97 \%$, respectively for eggs produced during summer season than those produced in winter season. The decrease of fertility (\%) in summer season may be due to the harsh environmental and hot weather conditions which might have induced stress in the cocks leading to reduce sexual activity and mating frequencies (Olawumi, 2015), or heat stress could be decrease the number of spermatozoa stored in the sperm host glands in the hen's reproductive tract (Brillard, 2003). Supporting to the current results, Awad (2013) found that both eggs fertility and hatchability $(\%)$ for Domyati ducks were significantly decreased in summer season than winter. On the other hand, all studied hatching traits and ducklings quality for Domyati ducks were significantly affected due to dietary LC supplementation except for early embryonic mortality and duckling's weight at hatch (Table 5). Fertility (\%) was significantly improved by $3.02,3.43$ and $2.62 \%$ for ducks fed diet supplemented with 150,300 and $600 \mathrm{mg} \mathrm{LC} / \mathrm{kg}$, respectively than those fed the control diet. This may be due to dietary LC supplementation plays a role in improving sexual activity and mating frequencies as well as increasing sperm concentration and semen quality. These results are in agreement with those reported by Nofal et al. (2006) who found that hens fed diet supplemented with $125 \mathrm{mg} \mathrm{LC} / \mathrm{kg}$ had higher fertility (\%) than those fed the control diet. However, Sarica et al (2007) reported that supplemental dietary LC did not significantly affected on fertility (\%) of Japanese quail breeders. Hatchability (\%) of fertile eggs was significantly improved by $11.25,11.62,9.12$ and $7.47 \%$, while total embryonic mortality (\%) was significantly decreased by 36.87, 38.16, 29.94 and $22.74 \%$ for eggs produced from ducks fed diet supplemented with 150, 300, 450 and $600 \mathrm{mg} \mathrm{LC} / \mathrm{kg}$, respectively as compared to the control. This improvement of hatchability and decreasing embryonic mortality may be due to LC concentration in the egg yolk, which may increase by its dietary supplementation (Peebles et al., 2007). Also, LC may play a beneficial role of embryonic development and newly hatched chicks by increasing energy production which needed for reduce the incidence of late dead embryos, in particularly during the piping process 
because it plays as an antioxidant to scavenge free radicals (Zhai et al., 2008). These results are in close agreement with those obtained by Baumgartner (2003) who reported that dietary LC supplementation $(50-100 \mathrm{mg} / \mathrm{kg}$ ) improved hatchability of breeding hens. Moreover, Thiemel and Jelinek (2004), Nofal et al. (2006) observed that hens fed diet supplemented with $125 \mathrm{mg} \mathrm{LC} / \mathrm{kg}$ diet increased hatchability of fertile eggs (\%) compared with those fed the control diet. Also, Al-Daraji and Tahir (2014a) revealed that hatchability of total set and fertile eggs was significantly improved, while embryonic mortality (\%) was significantly lowered by supplementing 150 $\mathrm{mg} \mathrm{LC/} \mathrm{kg}$ diet than the control for local ducks. First-grade duckling's (\%) was significantly improved by $7.04-7.80 \%$ with dietary LC supplementation (150-600 $\mathrm{mg} / \mathrm{kg}$ ), while second-grade duckling's was significantly decreased compared to the control. Moreover, hatched ducklings weight was not significantly affected due to dietary LC supplementation. This result is similar with those obtained by Zhai et al. (2008) who reported that chickens weight at hatch was not significantly affected by inovo injection with LC into fertile eggs at 17 or $18 \mathrm{~d}$ of incubation. The interaction between season and dietary LC supplementation had no significant effects on all studied hatching traits and ducklings quality except for hatchability and embryonic mortality (late and total). The best values of hatching traits and ducklings quality were recorded for ducks fed $150 \mathrm{mg}$ $\mathrm{LC} / \mathrm{kg}$ followed by 300 and $450 \mathrm{mg} \mathrm{LC} / \mathrm{kg}$ diet in winter season, whereas, the worst values of these traits were recorded for ducks fed the control diet in summer season. This deficient may be due to the chicks embryo may have limited capability to synthesize L-carnitine during incubation because gamma-butyrobetaine is limited in embryos and young animals due to the low activity of $\gamma$-butyrobetaine hydroxylase and it is required for biosynthesis of L-carnitine (Sato et al., 2006).

\section{Hematological parameters and ducks viability:-}

Hemoglobin (HB) and L cells (\%) were significantly decreased, while, WBC cells and $\mathrm{H}$ cells $(\%)$ as well as $\mathrm{H} / \mathrm{L}$ ratio were significantly increased for ducks reared in summer than those reared in winter season (Table 6). The low values of HB and $\mathrm{L}$ cells may be attributed to heat and nutritional stress during summer season, which impair the synthesis of blood cells in birds (Oladele et al., 2001). These results are in agreement with those obtained by Cetin et al. (2009) who demonstrated a decrease in leucocytes and lymphocytes (\%) during the months of July to October in Angora rabbits. Concerning LC supplementation to the diet, results showed that LC levels had significant effects on all hematological parameters except for WBC, which was not affected (Table 6). Hemoglobin was significantly increased by $10.50-12.88 \%$ for ducks fed diet supplemented with different LC levels than those fed the control diet. Lymphocyte cells (\%) was significantly high, while heterophlils cells (\%) was significantly low for ducks fed diet supplemented with 300 up to $600 \mathrm{mg} \mathrm{LC} / \mathrm{kg}$ than those fed the control diet, so that, H/L ratio was significantly decreased for these groups of ducks. All studied hematological parameters were significantly affected due to the interaction between season and dietary LC supplementation except for WBC. Ducks fed diet supplemented with 300 up to 600 $\mathrm{mg} \mathrm{LC} / \mathrm{kg}$ had higher values of HB or L cells compared with those fed the control diet in both summer and winter season and consequently, the best $\mathrm{H} / \mathrm{L}$ ratio. These results may be due to LC had strengthened immune function by enhancing antibody response (Deng et al., 2006). In addition, LC through its antioxidant properties increases the levels and activity of antioxidant enzymes such as glutathione 
peroxidase and superoxide dismutase in the plasma of poultry (Daşkıran et al., 2009). These results are keeping with those obtained by Jameel (2014) who reported that RBCs count and hemoglobin content were increased, while $\mathrm{H} / \mathrm{L}$ ratio was significantly decreased for chicks fed diet supplemented with $50 \mathrm{mg} \mathrm{LC/} \mathrm{Kg}$ as compared with those fed the control diet.

Ducks viability (\%) was significantly decreased for ducks reared in summer than winter season. Further, it was numerically higher by $0.94-5.43 \%$ for ducks fed different LC diets than the control (Table 6). The interactions between season and LC supplementation had no significant effect existed on viability (\%) of Domyati ducks during the experimental period (25-41 wks of age). All ducks fed diet supplemented with LC levels in winter season had higher viability (\%) than those fed the same diet under summer season. These results may be due to L-carnitine plays a major roles for cells protection from osmotic stress and represents the second line for cell defense against reactive oxygen species and their derivatives as it breaks free-radical chain reactions (termination of peroxidation) and prevents undesirable oxidation reactions (Arenas et al., 1998).

\section{Blood serum constituents:-}

Blood serum constituents of Domyati ducks were estimated to show the metabolic status of ducks and their health as affected by season, dietary LC supplementation and their interaction (Table 7). Ducks reared in summer season had significantly higher levels of serum triglycerides, total cholesterol, ALT and AST by 47.25, 19.80, 11.02 and $13.91 \%$, respectively as compared to those reared in winter season. Furthermore, all studied serum constituents were significantly affected due to LC supplementation except for total protein and triglycerides. Serum total cholesterol level was significantly decreased by $18.36,32.65$, 31.20 and $31.80 \%$ for ducks fed diet supplemented with $150,300,450$ and 600 mg LC/kg, respectively as compared with those fed the control diet. Liver enzymes (ALT\&AST) were significantly decreased by supplementing different LC levels than the control. All studied serum constituents were not significantly affected due to the interaction between season and dietary LC supplementation except of total cholesterol. Supplementing LC with $300 \mathrm{mg} / \mathrm{kg}$ diet in winter season recorded the lowest values of triglycerides and total cholesterol than other interactions. The decreases in total cholesterol and triglycerides levels might be attributed to acceleration of $\beta$ - oxidation of the long chain fatty acids as a result of dietary L-carnitine supplementation by its involvement in fatty acid movement into mitochondria for $\beta$-oxidation and production of acetyl CoA which may be used for controlling cholesterol and triglyceride biosynthesis, or it may be increased the activity of lipase and decrease activity of lipoprotein lipase, thereby leading to a higher concentration of fatty acid in serum by accelerating hydrolysis of triglycerides to glycerol and fatty acid, while reducing the concentration of triglycerides in serum. These results are in agreement with those obtained by Parizadian et al. (2011) who reported that quails fed diet supplemented with LC $(125-250 \mathrm{mg} / \mathrm{kg})$ had significantly lower blood triglyceride and total cholesterol in comparison with the control

\section{Nutrients digestibility and nutritive value:-}

The effects of season and dietary LC supplementation and their interaction on nutrients digestibility of the experimental diets are presented in Table 8. It is worthy to note that the digestion coefficient values of all nutrients were significantly affected due to season except for NFE. Digestibility coefficient values of DM, OM, CP, EE, CF, ash retention, TDN and ME were significantly decreased for ducks reared in summer season as compared with those reared in winter. These results may be due to 
reduce the absorptive area by heat stress, since villus height decreased and wet and dry weights per unit length of jejunum decreased as expected by Macleod (2004). The current results are in the same line with those obtained by Bonnet et al. (1997) who found that the digestibility of DM, CP, EE and starch as well as total mineral retention were significantly decreased under high temperature (summer) than low temperature (winter season) exposure. On the other hand, values of $\mathrm{OM}$ and $\mathrm{CP}$ digestibility and ashretention were significantly increased for ducks fed diet supplemented with 300 up to $600 \mathrm{mg} \mathrm{LC} / \mathrm{kg}$ as compared with those fed the control diet, while NFE digestibility was significantly improved by feeding these diets except for $450 \mathrm{mg} \mathrm{LC} / \mathrm{kg}$ diet. Moreover, values of TDN and ME (kcal/kg) were numerically improved by supplementing different LC levels to the diet than the control. Interaction between season and dietary LC supplementation had no significant effect on all nutrients digestibility except for CP and NFE which were significantly affected (Table 8 ). The best values of both TDN and ME $\mathrm{kcal} / \mathrm{kg}$ (nutritive value) were recorded for ducks fed diet supplemented with 150 and $300 \mathrm{mg}$ $\mathrm{LC} / \mathrm{kg}$ in winter season than other interactions. These results may be due to the ability of LC to improve the use of dietary nitrogen, whether directly through sparing its precursors (methionine and lysine) for protein biosynthesis and other cellular functions or indirectly by optimizing the balance between essential and non-essential amino acids within the cell (Daşkıran et al., 2009). Furthermore, it could be attributed to improvements in enzymatic digestion of nutrients, a high absorption capacity of the intestinal epithelium and enhanced fermentation activity of intestinal microflora (Ratriyanto et al., 2009). Also, improvement of ash retention may be due to LC improves short-chain fatty acids, originating from microbial fiber fermentation which may promote nutrient absorption due to electrophysiological changes in the enterocytes, resulting in improved mineral absorption and reduced endogenous secretion of minerals (Krishnan et al., 1999).

\section{Feeding economic efficiency:-}

Data of Table 9 show feeding economic efficiency (EE) as affected by season and dietary LC supplementation for Domyati ducks during the whole experimental period (25-41 wks of age). It is worthy to note that the total cost (feed and LC cost) value was significantly decreased by $13.05 \%$, while net return was significantly increased by $22.17 \%$ for ducks reared in summer than winter season. Moreover, feeding EE was significantly higher by $39.65 \%$ in summer than winter season. This improvement may be due to the decrease of feed consumption which resulted in more decrease of total feed cost although the decrease of total return, while the decrease of feeding EE in winter season may be due to more feed consumption which reflect the increase of total cost although the increase of net return. On the other hand, value of total cost was not significantly affected, while, total return and net return were significantly high for ducks fed diet supplement with different LC levels than those fed the control diet. Feeding EE was significantly improved by $51.49,55.45$, 47.52 and $34.16 \% / \mathrm{kg}$ for ducks fed 150 , 300,450 and $600 \mathrm{mg} \mathrm{LC} / \mathrm{kg}$ diet, respectively as compared to those fed the control diet. Interaction between season and dietary LC supplementation had significant effect on feeding total cost and EE, while total return was not statistically affected (Table 9). The best values of $\mathrm{EE}$ were recorded for ducks fed diet supplemented with all LC levels in summer season than other interactions, while the lowest value was recorded for ducks fed the control diet in winter season. These results could be due to the improvement of feed conversion, which reflect the improvement of net return per duck due to LC supplementation. 


\section{CONCLUSION}

Based on the present data, it is concluded that summer season had negative effects on productive and reproductive performance for local duck breeds, but dietary L-carnitine supplementation with
150 up to $450 \mathrm{mg} / \mathrm{kg}$ for Domyati ducks in summer season could be used to maximize and improve laying performance, hatchability traits, semen quality and nutrients digestibility coefficient as well as feeding economic efficiency.

Table 1: Composition and calculated analysis of the basal diet

\begin{tabular}{|l|c|}
\hline \multicolumn{1}{|c|}{ Ingredients } & \% \\
\hline Yellow corn & 65.40 \\
Soy bean meal (44 \%) & 22.00 \\
Corn gluten (60 \%) & 3.30 \\
Di-calcium phosphate & 1.80 \\
Limestone & 6.70 \\
Vit \& Min. premix 1 & 0.30 \\
NaCl & 0.40 \\
DL- Methionine (99\%) & 0.10 \\
\hline Total & $\mathbf{1 0 0}$ \\
\hline Calculated Analysis ${ }^{\mathbf{2}}$ & \\
\hline Crude protein \% & 16.82 \\
ME ( Kcal / kg ) & 2807 \\
Crude fiber \% & 3.18 \\
Ca. \% & 3.00 \\
Av. Phosph.\% & 0.45 \\
Lysine (\%) & 0.84 \\
Methionine $(\%)$ & 0.43 \\
Meth. + Cyst. (\%) & 0.71 \\
Na \% & 0.18 \\
\hline Price (LE/kg) & 3.324 \\
\hline
\end{tabular}

1- Each $3 \mathrm{~kg}$ of Vit and Min. premix contains 100 million IUVit A;2 million IU Vit.D3;10 g Vit.E; $1 \mathrm{~g}$ Vit.K3; $1 \mathrm{~g}$ Vit B1; $5 \mathrm{~g}$ Vit B2 ;10 mg Vit.B12 ; $1.5 \mathrm{~g}$ Vit B6; 30 $\mathrm{g}$ Niacin $; 10 \mathrm{~g}$ Pantothenic acid ; $1 \mathrm{~g}$ Folic acid;50 mg Biotin ; $300 \mathrm{~g}$ Choline chloride; $50 \mathrm{~g}$ Zinc; $4 \mathrm{~g}$ Copper; $0.3 \mathrm{~g}$ Iodine ; $30 \mathrm{~g}$ Iron; $0.1 \mathrm{~g}$ Selenium; 60g Manganese ;0.1 g Cobalt; and carrier $\mathrm{CaCO}_{3}$ to $3000 \mathrm{~g}$.

2- According to Feed Composition Tables for animal and poultry feedstuffs used in Egypt (2001).

3- Price of one $\mathrm{kg}$ (LE) at time of experiment for different ingredients : yellow corn, 2.65 ; Soy bean meal, 4.65 ; Corn gluten, 7.07; Di-calcium,8.0 ; limestone, 0.15 ; Vit\&Min.,25.0 ; Nacl,1.0 and Meth.,65.0. 
Table 2: Effect of season and dietary L-carnitine supplementation on egg number and mass for Domyati ducks.

\begin{tabular}{|c|c|c|c|c|c|c|c|c|c|c|c|c|}
\hline \multirow{2}{*}{\multicolumn{2}{|c|}{$\begin{array}{l}\text { Main } \\
\text { effects }\end{array}$}} & & \multicolumn{5}{|c|}{$\begin{array}{l}\text { Egg number per duck } \\
\text { Period (wks.) }\end{array}$} & \multicolumn{5}{|c|}{$\begin{array}{c}\text { Egg mass per duck (g) } \\
\text { Period (wks.) }\end{array}$} \\
\hline & & & $25-29$ & $29-33$ & 33-37 & $37-41$ & $25-41$ & $25-29$ & $29-33$ & 33-37 & $37-41$ & $25-41$ \\
\hline \multicolumn{13}{|c|}{ Season effect (S) } \\
\hline \multirow{2}{*}{\multicolumn{3}{|c|}{$\begin{array}{c}\text { Winter } \\
\text { Summer }\end{array}$}} & $19.00^{\mathrm{a}}$ & $20.33^{\mathbf{b}}$ & $19.74^{\mathrm{a}}$ & $20.08^{a}$ & $79.15^{a}$ & $1183.3^{\mathrm{a}}$ & $1328.6^{\mathbf{b}}$ & $1374.8^{\mathrm{a}}$ & $1479.6^{\mathrm{a}}$ & $5366.3^{a}$ \\
\hline & & & $17.10^{\mathbf{b}}$ & $21.39^{\mathrm{a}}$ & $18.46^{\mathrm{b}}$ & $17.10^{\mathbf{b}}$ & $74.05^{b}$ & $1055.7^{b}$ & $1388.4^{\mathrm{a}}$ & $1210.5^{\mathrm{b}}$ & $1137.0^{\mathbf{b}}$ & $4791.6^{b}$ \\
\hline \multicolumn{3}{|c|}{ Pooled SEM } & 0.23 & 0.20 & 0.24 & 0.23 & 0.52 & 12.3 & 10.2 & 20.4 & 21.3 & 39.6 \\
\hline \multicolumn{3}{|c|}{ Significance } & $*$ & $* *$ & $* *$ & *** & $* *$ & $* *$ & $* *$ & *** & $* *$ & $* *$ \\
\hline \multicolumn{13}{|c|}{ L-carnitine effect (LC, mg/kg) } \\
\hline & $17.17^{b}$ & $19.44^{\mathbf{b}}$ & $17.65^{\mathrm{b}}$ & $17.44^{\mathbf{b}}$ & $71.69^{b}$ & $1043.2^{\mathbf{b}}$ & $1240.6^{\mathbf{b}}$ & $1153.6^{\mathbf{b}}$ & $1189.2^{\mathbf{b}}$ & $4626.5^{\mathrm{b}}$ \\
\hline \multicolumn{3}{|c|}{150} & $18.13^{\mathrm{ab}}$ & $21.11^{\mathrm{a}}$ & $19.57^{\mathrm{a}}$ & $19.04^{\mathrm{a}}$ & $77.85^{\mathrm{a}}$ & $1117.7^{\mathrm{a}}$ & $1380.0^{\mathrm{a}}$ & $1365.6^{\mathbf{a}}$ & $1350.5^{\mathrm{a}}$ & $5213.8^{\mathbf{a}}$ \\
\hline \multicolumn{3}{|c|}{300} & $18.52^{\mathrm{a}}$ & $21.49^{\mathrm{a}}$ & $19.97^{\mathrm{a}}$ & $18.93^{\mathrm{a}}$ & $78.91^{\mathrm{a}}$ & $1148.7^{\mathrm{a}}$ & $1399.0^{\mathrm{a}}$ & $1361.2^{\mathrm{a}}$ & $1316.9^{a}$ & $5225.8^{a}$ \\
\hline \multicolumn{3}{|c|}{450} & $18.39^{\mathrm{a}}$ & $21.32^{\mathrm{a}}$ & $18.96^{\mathrm{a}}$ & $18.83^{\mathrm{a}}$ & $77.50^{\mathrm{a}}$ & $1154.1^{\mathrm{a}}$ & $1396.0^{\mathrm{a}}$ & $1275.6^{\mathrm{a}}$ & $1342.0^{\mathrm{a}}$ & $5167.7^{\mathrm{a}}$ \\
\hline \multicolumn{3}{|c|}{600} & $18.05^{\mathrm{ab}}$ & $20.94^{\mathrm{a}}$ & $19.34^{\mathrm{a}}$ & $18.71^{\mathrm{a}}$ & $77.04^{\mathrm{a}}$ & $1133.8^{\mathrm{a}}$ & $1376.9^{\mathrm{a}}$ & $1307.3^{\mathrm{a}}$ & $1343.0^{\mathrm{a}}$ & $5161.0^{\mathrm{a}}$ \\
\hline \multicolumn{3}{|c|}{ Pooled SEM } & 0.36 & 0.31 & 0.38 & 0.36 & 00.82 & 19.5 & 16.2 & 22.3 & 33.7 & 62.6 \\
\hline \multicolumn{3}{|c|}{ Significance } & $*$ & $* *$ & ** & $* *$ & $* *$ & $* *$ & $* *$ & $* *$ & *** & $* *$ \\
\hline \multirow{11}{*}{ 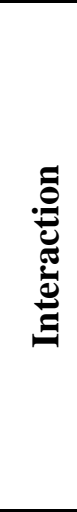 } & S. & $\mathrm{LC}$ & & & & & & & & & & \\
\hline & & 0.0 & 18.23 & 18.70 & $17.67^{\mathfrak{c}}$ & $19.11^{\mathrm{a}}$ & $73.71^{b c}$ & 1103.3 & 1206.5 & $1209.9^{\mathbf{b c}}$ & $1361.7^{\text {ab }}$ & $4881.4^{c}$ \\
\hline & & 150 & 19.08 & 20.75 & $21.37^{\mathrm{a}}$ & $20.89^{a}$ & $82.08^{a}$ & 1176.7 & 1373.3 & $1568.2^{a}$ & $1560.9^{a}$ & $5679.1^{\mathrm{a}}$ \\
\hline & $\stackrel{\Xi}{\Xi}$ & 300 & 19.37 & 21.23 & $20.04^{\mathrm{a}}$ & $19.84^{\mathrm{a}}$ & $80.46^{\mathrm{a}}$ & 1196.7 & 1367.9 & $1376.8^{a}$ & $1457.2^{\mathrm{a}}$ & $5398.5^{a b}$ \\
\hline & & 450 & 19.20 & 20.68 & $19.50^{\text {ab }}$ & $20.33^{a}$ & $79.70^{\mathrm{a}}$ & 1233.3 & 1361.4 & $1341.2^{\mathrm{ab}}$ & $1498.9^{a}$ & $5434.9^{a}$ \\
\hline & & 600 & 19.13 & 20.30 & $20.10^{\mathrm{a}}$ & $20.26^{\mathrm{a}}$ & $79.80^{\mathrm{a}}$ & 1206.7 & 1333.9 & $1377.9^{a}$ & $1519.2^{\mathrm{a}}$ & $5437.7^{\mathrm{a}}$ \\
\hline & & 0.0 & 16.11 & 20.17 & $17.63^{c}$ & $15.77^{\mathrm{c}}$ & $69.68^{c}$ & 983.0 & 1274.7 & $1097.3^{d}$ & $1016.7^{b}$ & $4371.7^{d}$ \\
\hline & ¿ & 150 & 17.18 & 21.47 & $17.77^{\mathrm{c}}$ & $17.20^{\mathrm{bc}}$ & $73.62^{\text {bc }}$ & 1058.8 & 1386.7 & $1163.0^{\text {cd }}$ & $1140.0^{b}$ & $4748.5^{\mathrm{cd}}$ \\
\hline & छ & 300 & 17.67 & 21.77 & $19.90^{\text {ab }}$ & $18.02^{\mathbf{a b}}$ & $77.36^{\mathrm{b}}$ & 1100.7 & 1430.0 & $1345.7^{\mathrm{ab}}$ & $1176.7^{b}$ & $5053.0^{\mathbf{b c}}$ \\
\hline & $\Xi$ & 450 & 17.57 & 21.97 & $18.42^{\mathrm{bc}}$ & $17.34^{b c}$ & $75.31^{b}$ & 1074.9 & 1430.7 & $1210.0^{\mathbf{b c}}$ & $1185.0^{b}$ & $4900.6^{c}$ \\
\hline & & 600 & 16.96 & 21.58 & $18.58^{\text {bc }}$ & $17.16^{\mathrm{bc}}$ & $74.28^{b}$ & 1061.0 & 1420.0 & $1236.7^{\mathbf{b c}}$ & $1166.7^{b}$ & $4884.3^{c}$ \\
\hline \multicolumn{3}{|c|}{ Pooled SEM } & 0.77 & 0.51 & 0.44 & 0.54 & 0.51 & 1.16 & 22.8 & 45.7 & 47.6 & 88.5 \\
\hline \multicolumn{3}{|c|}{ Significance } & NS & NS & $* *$ & $* *$ & $* *$ & NS & NS & $* *$ & ** & $*$ \\
\hline
\end{tabular}

a,b :means in the same column and effect bearing different superscripts are significantly different $(\mathrm{P} \leq 0.05)$. SEM= standard error mean $\mathrm{NS}=$ non-significant; $*=\mathrm{P} \leq 0.05 ; * *=\mathrm{P} \leq 0.01$ 
Table 3: Effect of season and dietary L-carnitine supplementation on feed consumption and conversion for Domyati ducks

\begin{tabular}{|c|c|c|c|c|c|c|c|c|c|c|c|c|}
\hline \multirow{2}{*}{\multicolumn{3}{|c|}{ Main effects }} & \multicolumn{5}{|c|}{$\begin{array}{l}\text { Feed consumption (g/duck) } \\
\text { Period (wks) }\end{array}$} & \multicolumn{5}{|c|}{$\begin{array}{c}\text { Feed conversion (kg feed/ kg egg mass) } \\
\text { Period (wks) }\end{array}$} \\
\hline & & & $25-29$ & $29-33$ & 33-37 & $37-41$ & $25-41$ & $25-29$ & $29-33$ & 33-37 & $37-41$ & $25-41$ \\
\hline \multicolumn{13}{|c|}{ Season effect $(\mathrm{S})$} \\
\hline \multirow{2}{*}{\multicolumn{3}{|c|}{$\begin{array}{c}\text { Winter } \\
\text { Summer }\end{array}$}} & $4098.7^{\mathrm{a}}$ & $4952.7^{\mathrm{a}}$ & $4982.0^{\mathrm{a}}$ & $4943.3^{\mathrm{a}}$ & $18976.7^{\mathrm{a}}$ & $3.48^{\mathrm{b}}$ & $3.75^{\mathrm{a}}$ & $3.66^{\mathrm{a}}$ & $3.36^{\mathbf{b}}$ & $3.55^{\mathrm{a}}$ \\
\hline & & & $3928.7^{\mathbf{b}}$ & $4435.3^{\mathbf{b}}$ & $4107.3^{\mathbf{b}}$ & $4022.0^{\mathbf{b}}$ & $16493.3^{b}$ & $3.73^{\mathrm{a}}$ & $3.20^{\mathbf{b}}$ & $3.41^{\mathrm{b}}$ & $3.55^{\mathrm{a}}$ & $3.45^{\mathrm{b}}$ \\
\hline \multicolumn{3}{|c|}{ Pooled SEM } & 32.1 & 32.9 & 48.9 & 38.4 & 79.6 & 0.04 & 0.04 & 0.06 & 0.04 & 0.03 \\
\hline \multicolumn{3}{|c|}{ Significance } & $* *$ & $* *$ & *** & $* *$ & $* *$ & $* *$ & $* *$ & $* *$ & $* *$ & $* *$ \\
\hline \multicolumn{13}{|c|}{ L-carnitine effect (LC, mg/kg) } \\
\hline \multicolumn{3}{|c|}{0.0} & $4135.0^{\mathrm{a}}$ & 4761.7 & 4608.3 & 4573.3 & $18078.3^{\mathrm{a}}$ & $3.97^{\mathrm{a}}$ & $3.85^{\mathrm{a}}$ & $3.99^{\mathrm{a}}$ & $3.86^{\mathrm{a}}$ & $3.90^{\mathrm{a}}$ \\
\hline \multicolumn{3}{|c|}{150} & $4081.7^{\mathbf{a b}}$ & 4620.0 & 4571.7 & 4526.7 & $17800.0^{\mathbf{a b}}$ & $3.66^{\mathrm{b}}$ & $3.35^{\mathrm{b}}$ & $3.37^{\mathrm{b}}$ & $3.38^{\mathrm{b}}$ & $3.42^{\mathrm{b}}$ \\
\hline \multicolumn{3}{|c|}{300} & $3955.0^{b}$ & 4731.7 & 4616.7 & 4433.3 & $17736.7^{\mathbf{a b}}$ & $3.45^{\mathrm{c}}$ & $3.39^{\mathrm{b}}$ & $3.39^{\mathrm{b}}$ & $3.38^{\mathrm{b}}$ & $3.39^{\mathrm{b}}$ \\
\hline \multicolumn{3}{|c|}{450} & $3945.0^{\mathrm{b}}$ & 4656.7 & 4443.3 & 4440.0 & $17485.0^{\mathbf{b}}$ & $3.43^{\mathrm{c}}$ & $3.34^{\mathrm{b}}$ & $3.48^{\mathrm{b}}$ & $3.32^{\mathrm{b}}$ & $3.38^{\mathrm{b}}$ \\
\hline \multicolumn{3}{|c|}{600} & $3951.7^{\mathbf{b}}$ & 4700.0 & 4483.3 & 4440.0 & $17575.0^{\mathbf{b}}$ & $3.50^{\mathrm{bc}}$ & $3.42^{\mathrm{b}}$ & $3.44^{\mathrm{b}}$ & $3.33^{\mathrm{b}}$ & $3.41^{\mathrm{b}}$ \\
\hline \multicolumn{3}{|c|}{ Pooled SEM } & 50.8 & 52.0 & 77.3 & 60.7 & 125.9 & 0.06 & 0.06 & 0.10 & 0.07 & 0.05 \\
\hline \multicolumn{3}{|c|}{ Significance } & $*$ & NS & NS & NS & $*$ & $* *$ & $* *$ & $* *$ & $* *$ & $* *$ \\
\hline \multirow{11}{*}{ 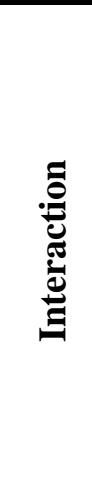 } & S. & $\mathrm{LC}$ & & & & & & & & & & \\
\hline & & 0.0 & 4300.0 & $5190.0^{a}$ & $5250.0^{\mathrm{a}}$ & $5193.3^{a}$ & $19933.3^{\mathbf{a}}$ & 3.90 & $4.30^{\mathrm{a}}$ & 4.36 & 3.82 & $4.08^{\mathrm{a}}$ \\
\hline & & 150 & 4080.0 & $4916.7^{a}$ & $5160.0^{\mathrm{a}}$ & $5023.3^{\mathrm{a}}$ & $19180.0^{\mathrm{a}}$ & 3.47 & $3.58^{\mathrm{b}}$ & 3.31 & 3.22 & $3.38^{\mathrm{c}}$ \\
\hline & $\stackrel{\varrho}{\Xi}$ & 300 & 4046.7 & $4873.3^{\mathrm{ab}}$ & $4826.7^{\mathrm{ab}}$ & $4786.7^{\mathrm{a}}$ & $18533.3^{\mathrm{a}}$ & 3.39 & $3.57^{\mathrm{b}}$ & 3.51 & 3.29 & $3.44^{b c}$ \\
\hline & $\bar{z}$ & 450 & 4016.7 & $4826.7^{\text {ab }}$ & $4850.0^{\mathbf{a b}}$ & $4840.0^{\mathbf{a}}$ & $18533.3^{\mathrm{a}}$ & 3.26 & $3.55^{\mathrm{b}}$ & 3.63 & 3.23 & $3.41^{\mathrm{c}}$ \\
\hline & & 600 & 4050.0 & $4956.7^{a}$ & $4823.3^{a b}$ & $4873.3^{\mathrm{a}}$ & $18703.3^{\mathrm{a}}$ & 3.37 & $3.72^{\mathbf{b}}$ & 3.51 & 3.22 & $3.45^{\mathrm{bc}}$ \\
\hline & & 0.0 & 3970.0 & $4333.3^{c}$ & $3966.7^{d}$ & $3953.3^{\mathbf{b}}$ & $16223.3^{b}$ & 4.04 & $3.40^{\mathrm{bc}}$ & 3.62 & 3.90 & $3.71^{b}$ \\
\hline & $\bar{d}$ & 150 & 4083.3 & $4323.3^{c}$ & $3983.3^{d}$ & $4030.0^{\mathbf{b}}$ & $16420.0^{b}$ & 3.86 & $3.12^{\mathrm{c}}$ & 3.43 & 3.54 & $3.46^{\mathrm{bc}}$ \\
\hline & $\Xi$ & 300 & 3863.3 & $4590.0^{\text {bc }}$ & $4406.7^{\text {bc }}$ & $4080.0^{\mathbf{b}}$ & $16940.0^{b}$ & 3.52 & $3.21^{\mathrm{c}}$ & 3.27 & 3.47 & $3.35^{\mathrm{c}}$ \\
\hline & छ & 450 & 3873.3 & $4486.7^{\mathrm{c}}$ & $4036.7^{\mathrm{cd}}$ & $4040.0^{\mathbf{b}}$ & $16436.7^{b}$ & 3.60 & $3.14^{\mathrm{c}}$ & 3.34 & 3.41 & $3.36^{\mathrm{c}}$ \\
\hline & $\bar{n}$ & 600 & 3853.3 & $4443.3^{c}$ & $4143.3^{\text {cd }}$ & $4006.7^{b}$ & $16446.7^{b}$ & 3.63 & $3.13^{\mathrm{c}}$ & 3.37 & 3.45 & $3.37^{\mathrm{c}}$ \\
\hline \multicolumn{3}{|c|}{ Pooled SEM } & 71.8 & 73.6 & 109.4 & 85.8 & 178.1 & 0.09 & 0.09 & 0.14 & 0.09 & 0.07 \\
\hline \multicolumn{3}{|c|}{ Significance } & NS & $* *$ & $* *$ & $*$ & $* *$ & NS & $*$ & NS & NS & $*$ \\
\hline
\end{tabular}

a,b :means in the same column and effect bearing different superscripts are significantly different $(\mathrm{P} \leq 0.05)$. SEM= standard error mean

$\mathrm{NS}=$ non-significant; $*=\mathrm{P} \leq 0.05 ; * *=\mathrm{P} \leq 0.01$ 
Table 4: Effect of season and dietary L-carnitine supplementation on semen quality parameters for Domyati drakes.

\begin{tabular}{|c|c|c|c|c|c|c|c|c|}
\hline \multirow{2}{*}{\multicolumn{3}{|c|}{ Main effect }} & \multirow[b]{2}{*}{$\begin{array}{l}\text { Volume } \\
\text { (ml) }\end{array}$} & \multirow[b]{2}{*}{$\begin{array}{c}\text { Conc. } \\
\left(\times 10^{6} / \mathrm{mm}^{3}\right)\end{array}$} & \multicolumn{4}{|c|}{ Sperms, \% } \\
\hline & & & & & Live & Dead & Abnormal & $\begin{array}{c}\text { Mass } \\
\text { motility }\end{array}$ \\
\hline \multicolumn{9}{|c|}{ Season effect $(S)$} \\
\hline \multirow{2}{*}{\multicolumn{3}{|c|}{$\begin{array}{c}\text { Winter } \\
\text { Summer }\end{array}$}} & $0.38^{\mathrm{a}}$ & $2.72^{\mathrm{a}}$ & 93.58 & 6.42 & $12.75^{b}$ & $76.45^{\mathrm{a}}$ \\
\hline & & & $0.33^{\mathbf{b}}$ & $2.43^{b}$ & 93.71 & 6.29 & $16.19^{\mathrm{a}}$ & $73.97^{\mathbf{b}}$ \\
\hline \multicolumn{3}{|c|}{ Pooled SEM } & 0.13 & 0.08 & 0.23 & 0.22 & 0.40 & 0.46 \\
\hline \multicolumn{3}{|c|}{ Significance } & $*$ & $*$ & NS & NS & $*$ & $*$ \\
\hline \multicolumn{9}{|c|}{ L-carnitine effect (LC, mg/kg) } \\
\hline \multicolumn{3}{|c|}{0.0} & $0.32^{\mathrm{c}}$ & $2.13^{b}$ & $91.75^{b}$ & $8.25^{\mathrm{a}}$ & $16.87^{\mathrm{a}}$ & $73.13^{\mathrm{c}}$ \\
\hline \multicolumn{3}{|c|}{150} & $0.34^{\text {bc }}$ & $2.67^{\mathrm{a}}$ & $94.05^{\mathrm{a}}$ & 5.95 bc & $15.93^{\mathrm{a}}$ & 74.17 bc \\
\hline \multicolumn{3}{|c|}{300} & $0.36^{\mathrm{ab}}$ & $2.62^{\mathrm{a}}$ & $93.90^{\mathrm{a}}$ & $6.10^{b}$ & $14.48^{\mathbf{a b}}$ & $76.24^{\mathrm{ab}}$ \\
\hline \multicolumn{3}{|c|}{450} & $0.39^{\mathrm{a}}$ & $2.76^{\mathrm{a}}$ & $93.78^{a}$ & $6.22^{b}$ & $12.63^{b}$ & $75.39^{\mathbf{a b}}$ \\
\hline \multicolumn{3}{|c|}{600} & $0.36^{\mathrm{ab}}$ & $2.69^{\mathrm{a}}$ & $94.73^{a}$ & $5.27^{\mathrm{c}}$ & $12.44^{b}$ & $77.11^{\mathrm{a}}$ \\
\hline \multicolumn{3}{|c|}{ Pooled SEM } & 0.20 & 0.12 & 0.36 & 0.35 & 0.64 & 0.72 \\
\hline \multicolumn{3}{|c|}{ Significance } & $*$ & $* *$ & $* *$ & $* *$ & $* *$ & $* *$ \\
\hline \multirow{11}{*}{ 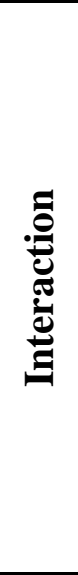 } & $\mathbf{S .}$ & $\mathbf{L C}$ & & & & & & \\
\hline & \multirow{5}{*}{ 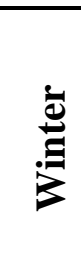 } & 0.0 & 0.37 & 2.25 & 92.10 & 7.90 & $16.67^{\mathrm{a}}$ & $73.67^{b}$ \\
\hline & & 150 & 0.38 & 2.72 & 93.33 & 6.67 & $15.03^{\mathrm{a}}$ & $74.40^{b}$ \\
\hline & & 300 & 0.36 & 2.94 & 94.00 & 6.00 & $12.13^{b c}$ & $77.50^{\mathrm{a}}$ \\
\hline & & 450 & 0.39 & 2.97 & 93.63 & 6.37 & $9.73^{c}$ & $76.33^{a b}$ \\
\hline & & 600 & 0.38 & 2.74 & 94.83 & 5.17 & $10.17^{\mathrm{c}}$ & $80.33^{a}$ \\
\hline & \multirow{5}{*}{ 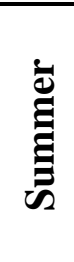 } & $\mathbf{0 . 0}$ & 0.27 & 2.02 & 91.40 & 8.60 & $17.07^{\mathrm{a}}$ & $72.60^{b}$ \\
\hline & & 150 & 0.30 & 2.62 & 94.77 & 5.23 & $16.83^{a}$ & $73.94^{b}$ \\
\hline & & 300 & 0.35 & 2.29 & 93.80 & 6.20 & $16.83^{a}$ & $74.97^{\mathbf{b}}$ \\
\hline & & 450 & 0.38 & 2.56 & 93.93 & 6.07 & $15.53^{\mathrm{a}}$ & $74.44^{\mathbf{b}}$ \\
\hline & & 600 & 0.35 & 2.65 & 94.63 & 5.37 & $14.70^{\mathrm{ab}}$ & $73.88^{\mathbf{b}}$ \\
\hline \multicolumn{3}{|c|}{ Pooled SEM } & 0.03 & 0.17 & 0.50 & 0.49 & 0.90 & 1.02 \\
\hline \multicolumn{3}{|c|}{ Significance } & NS & NS & $\mathbf{N S}$ & $\mathbf{N S}$ & $* *$ & $*$ \\
\hline
\end{tabular}

a,b..c :means in the same column and effect bearing different superscripts are significantly different $(\mathrm{P} \leq 0.05)$.

$\mathrm{SEM}=$ standard error mean $; \mathrm{NS}=$ non-significant $; *=\mathrm{P} \leq 0.05 ; * *=\mathrm{P} \leq 0.01$ 
Table( 5): Effect of season and dietary L-carnitine supplementation on hatchability traits and duckling quality for Domyati ducks.

\begin{tabular}{|c|c|c|c|c|c|c|c|c|c|c|}
\hline \multirow{2}{*}{\multicolumn{3}{|c|}{ Main Parameters }} & \multicolumn{5}{|c|}{$\%$} & \multirow{2}{*}{$\begin{array}{c}\text { Hatched } \\
\text { chick wt. (g) }\end{array}$} & \multicolumn{2}{|c|}{ Ducklings grade , \% } \\
\hline & & & Fertility & $\begin{array}{c}\text { Hatch of } \\
\text { fertile egg }\end{array}$ & $\begin{array}{c}\text { Early } \\
\text { EM }\end{array}$ & $\begin{array}{l}\text { Late } \\
\text { EM }\end{array}$ & $\begin{array}{l}\text { Total } \\
\text { EM }\end{array}$ & & $\mathbf{1}^{\text {th }}$ & $2^{\text {nd }}$ \\
\hline \multicolumn{11}{|c|}{ Season effect $(\mathrm{S})$} \\
\hline \multirow{2}{*}{\multicolumn{3}{|c|}{$\begin{array}{l}\text { Winter } \\
\text { Summer }\end{array}$}} & $90.17^{\mathbf{a}}$ & $89.30^{\mathrm{a}}$ & $2.37^{\mathbf{b}}$ & $8.33^{\mathbf{b}}$ & $10.70^{\mathbf{b}}$ & 40.33 & 95.07 & 4.93 \\
\hline & & & $87.58^{\mathbf{b}}$ & $75.93^{b}$ & $5.20^{\mathrm{a}}$ & $18.87^{\mathrm{a}}$ & $24.07^{\mathrm{a}}$ & 40.21 & 94.55 & 5.45 \\
\hline \multicolumn{3}{|c|}{ Pooled SEM } & 0.56 & 0.92 & 0.25 & 0.98 & 0.92 & 0.35 & 0.34 & 0.34 \\
\hline \multicolumn{3}{|c|}{ Significance } & $* *$ & $* *$ & $* *$ & $* *$ & $* *$ & NS & $\mathbf{N S}$ & $\mathbf{N S}$ \\
\hline \multicolumn{11}{|c|}{ L-carnitine effect $(\mathrm{LC}, \mathrm{mg} / \mathrm{kg})$} \\
\hline \multirow{5}{*}{\multicolumn{3}{|c|}{$\begin{array}{l}0.0 \\
150 \\
300 \\
450 \\
600\end{array}$}} & $87.07^{\mathbf{b}}$ & $76.65^{b}$ & 4.46 & $18.89^{\mathrm{a}}$ & $23.35^{\mathrm{a}}$ & 40.03 & $89.57^{b}$ & $10.43^{\mathrm{a}}$ \\
\hline & & & $89.70^{\mathrm{a}}$ & $85.26^{\mathrm{a}}$ & 3.38 & $11.36^{\mathrm{b}}$ & $14.74^{b}$ & 40.54 & $95.88^{\mathrm{a}}$ & $4.12^{b}$ \\
\hline & & & $90.06^{\mathrm{a}}$ & $85.56^{\mathrm{a}}$ & 3.61 & $10.83^{b}$ & $14.44^{\mathrm{b}}$ & 40.21 & $96.06^{\mathrm{a}}$ & $3.94^{b}$ \\
\hline & & & $88.21^{\text {ab }}$ & $83.64^{\mathrm{a}}$ & 3.66 & $12.70^{\mathrm{b}}$ & $16.36^{b}$ & 40.69 & $95.99^{\mathrm{a}}$ & $4.01^{b}$ \\
\hline & & & $89.35^{\mathrm{a}}$ & $81.96^{\mathrm{a}}$ & 3.82 & $14.22^{b}$ & $18.04^{b}$ & 39.87 & $96.56^{\mathrm{a}}$ & $3.44^{b}$ \\
\hline \multicolumn{3}{|c|}{ Pooled SEM } & 0.88 & 1.46 & 0.40 & 1.55 & 1.46 & 0.55 & 0.54 & 0.54 \\
\hline \multicolumn{3}{|c|}{ Significance } & $*$ & $* *$ & $\mathbf{N S}$ & $* *$ & $* *$ & NS & $* *$ & $* *$ \\
\hline \multirow{11}{*}{ 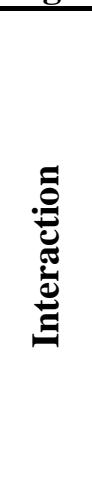 } & S. & LC & & & & & & & & \\
\hline & & 0.0 & 89.75 & $86.04^{b}$ & 3.16 & $10.80^{c}$ & $13.96^{c}$ & 40.97 & 88.92 & 11.08 \\
\hline & $\bar{a}$ & 150 & 91.40 & $91.97^{\mathrm{a}}$ & 2.01 & $6.02^{c}$ & 8.03 & 40.50 & 97.09 & 2.91 \\
\hline & $\stackrel{\mathscr{U}}{\Xi}$ & 300 & 90.30 & $91.57^{\mathrm{a}}$ & 2.32 & $6.11^{c}$ & $8.43^{\mathrm{c}}$ & 40.63 & 95.85 & 4.15 \\
\hline & 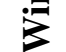 & 450 & 90.00 & $88.89^{\mathrm{a}}$ & 2.22 & $8.89^{c}$ & $11.11^{\mathrm{c}}$ & 40.00 & 96.67 & 3.33 \\
\hline & & 600 & 89.42 & $88.05^{\mathrm{ab}}$ & 2.11 & $9.84^{\mathrm{c}}$ & $11.95^{\mathrm{c}}$ & 39.57 & 96.84 & 3.16 \\
\hline & & 0.0 & 84.39 & $67.26^{d}$ & 5.76 & $26.98^{\mathrm{a}}$ & $32.74^{\mathrm{a}}$ & 39.10 & 90.21 & 9.79 \\
\hline & $\dot{\bar{d}}$ & 150 & 88.00 & $78.56^{\mathrm{c}}$ & 4.74 & $16.70^{b}$ & $21.44^{b}$ & 40.59 & 94.67 & 5.33 \\
\hline & छ & 300 & 89.81 & $79.55^{\mathrm{c}}$ & 4.91 & $15.54^{b}$ & $20.45^{b}$ & 39.79 & 96.27 & 3.73 \\
\hline & $\Xi$ & 450 & 86.41 & $78.39^{c}$ & 5.10 & $16.51^{b}$ & $21.61^{b}$ & 41.39 & 95.31 & 4.69 \\
\hline & & 600 & 89.27 & $75.87^{\mathrm{c}}$ & 5.53 & $18.60^{b}$ & $24.13^{\mathrm{ab}}$ & 40.18 & 96.27 & 3.73 \\
\hline \multicolumn{3}{|c|}{ Pooled SEM } & 1.24 & 2.06 & 0.57 & 2.19 & 2.06 & 0.77 & 0.76 & 0.76 \\
\hline \multicolumn{3}{|c|}{ Significance } & $\mathbf{N S}$ & $*$ & $\mathbf{N S}$ & $*$ & $*$ & $\mathbf{N S}$ & $\mathbf{N S}$ & $\mathbf{N S}$ \\
\hline
\end{tabular}

a,b..c :means in the same column and effect bearing different superscripts are significantly different $(\mathrm{P} \leq 0.05)$.

$\mathrm{SEM}=$ standard error mean; EM: embryonic mortality; $\mathrm{NS}=$ non-significant; $*=\mathrm{P} \leq 0.05 ; * *=\mathrm{P} \leq 0.01$ 
Table 6: Effect of season and dietary L-carnitine supplementation on hematological parameters and viability (\%) for Domyati ducks.

\begin{tabular}{|c|c|c|c|c|c|c|c|c|}
\hline & \multirow{2}{*}{$\underset{(\mathrm{g} / \mathrm{dl})}{\mathbf{H B}}$} & \multirow{2}{*}{$\begin{array}{c}\text { WBC } \\
\left(\mathrm{x} 10^{3} / \mathrm{mm}^{3}\right)\end{array}$} & \multicolumn{2}{|c|}{ Count, \% } & \multirow{2}{*}{$\mathbf{H} / \mathbf{L}$} & \multirow{2}{*}{ Viability, \% } \\
\hline & & & & & $\mathbf{H}$ & $\mathbf{L}$ & & \\
\hline \multicolumn{9}{|c|}{ Season effect $(S)$} \\
\hline \multirow{2}{*}{\multicolumn{3}{|c|}{$\begin{array}{l}\text { Winter } \\
\text { Summer } \\
\end{array}$}} & $13.33^{\mathrm{a}}$ & $20.13^{\mathbf{b}}$ & $18.73^{\mathbf{b}}$ & $81.33^{\mathrm{a}}$ & $0.23^{\mathbf{b}}$ & $98.25^{\mathrm{a}}$ \\
\hline & & & $12.43^{\mathbf{b}}$ & $30.53^{\mathrm{a}}$ & $27.67^{\mathbf{a}}$ & $72.33^{\mathbf{b}}$ & $0.38^{\mathrm{a}}$ & $94.67^{b}$ \\
\hline \multicolumn{3}{|c|}{ Pooled SEM } & 0.20 & 0.59 & 0.50 & 0.50 & 0.01 & 1.02 \\
\hline \multicolumn{3}{|c|}{ Significance } & $*$ & $* *$ & $* *$ & $* *$ & $* *$ & $*$ \\
\hline \multicolumn{9}{|c|}{ L-carnitine effect (LC, mg/kg) } \\
\hline \multicolumn{3}{|c|}{0.0} & $11.80^{b}$ & 26.83 & $27.50^{\mathrm{a}}$ & $72.50^{b}$ & $0.38^{\mathrm{a}}$ & 93.80 \\
\hline \multicolumn{3}{|c|}{150} & $13.09^{\mathrm{a}}$ & 25.00 & $26.33^{\mathrm{a}}$ & $73.67^{\mathbf{b}}$ & $0.36^{\mathrm{a}}$ & 94.68 \\
\hline \multicolumn{3}{|c|}{300} & $13.15^{\mathrm{a}}$ & 25.17 & $21.67^{\mathbf{b}}$ & $78.33^{\mathrm{a}}$ & $0.28^{\mathbf{b}}$ & 98.89 \\
\hline \multicolumn{3}{|c|}{450} & $13.04^{\mathrm{a}}$ & 24.83 & $19.83^{\mathbf{b}}$ & $80.17^{\mathbf{a}}$ & $0.25^{b}$ & 98.02 \\
\hline \multicolumn{3}{|c|}{600} & $13.32^{\mathrm{a}}$ & 24.83 & $20.67^{\mathbf{b}}$ & $79.50^{a}$ & $0.26^{\mathbf{b}}$ & 96.91 \\
\hline \multicolumn{3}{|c|}{ Pooled SEM } & 0.31 & 0.93 & 0.80 & 0.80 & 0.01 & 1.61 \\
\hline \multicolumn{3}{|c|}{ Significance } & $* *$ & $\mathbf{N S}$ & $* *$ & $* *$ & $* *$ & $\mathbf{N S}$ \\
\hline \multirow{11}{*}{ 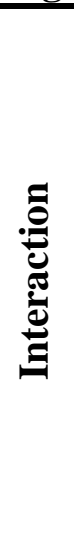 } & S. & $\mathbf{L C}$ & & & & & & \\
\hline & & 0.0 & $12.00^{\mathbf{b c}}$ & 22.00 & $21.00^{b c}$ & $79.00^{\mathbf{a b}}$ & $0.27^{\mathrm{c}}$ & 96.49 \\
\hline & & 150 & $13.53^{\mathrm{a}}$ & 20.00 & $20.33^{b c}$ & $79.67^{\mathbf{a b}}$ & $0.26^{\mathrm{c}}$ & 98.25 \\
\hline & $\stackrel{\mathscr{B}}{=}$ & 300 & $13.40^{\mathrm{a}}$ & 20.67 & $17.00^{\mathrm{c}}$ & $83.00^{\mathrm{a}}$ & $0.20^{\mathrm{c}}$ & 100.00 \\
\hline & 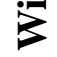 & 450 & $13.53^{\mathrm{a}}$ & 19.33 & $17.67^{\mathrm{c}}$ & $82.33^{\mathrm{a}}$ & $0.21^{\mathrm{c}}$ & 98.25 \\
\hline & & 600 & $14.20^{\mathrm{a}}$ & 18.67 & $17.67^{\mathrm{c}}$ & $82.67^{a}$ & $0.21^{\mathbf{c}}$ & 98.25 \\
\hline & & 0.0 & $11.60^{\mathrm{c}}$ & 31.67 & $34.00^{\mathrm{a}}$ & $66.00^{d}$ & $0.52^{\mathrm{a}}$ & 91.11 \\
\hline & $\grave{g}$ & 150 & $12.65^{b}$ & 30.00 & $32.33^{a}$ & $67.67^{d}$ & $0.48^{\mathrm{a}}$ & 91.11 \\
\hline & $\Xi$ & 300 & $12.90^{b}$ & 29.67 & $26.33^{a b}$ & $73.67^{\mathrm{c}}$ & $0.36^{\mathbf{b}}$ & 97.78 \\
\hline & $\Xi$ & 450 & $12.55^{b}$ & 30.33 & $22.00^{\mathbf{b c}}$ & $78.00^{b c}$ & $0.28^{\mathbf{c}}$ & 97.78 \\
\hline & & 600 & $12.43^{b c}$ & 31.00 & $23.67^{\mathbf{b}}$ & $76.33^{c}$ & $0.31^{\mathbf{b c}}$ & 95.56 \\
\hline \multicolumn{3}{|c|}{ Pooled SEM } & 0.44 & 1.32 & 1.13 & 1.13 & 0.02 & 2.28 \\
\hline \multicolumn{3}{|c|}{ Significance } & $*$ & $\mathbf{N S}$ & $* *$ & $* *$ & $* *$ & NS \\
\hline
\end{tabular}

$\mathrm{HB}=$ hemoglobin; $\mathrm{WBC}=$ white blood cells; $\mathrm{H}=$ heterophils cells; $\mathrm{L}=$ lymphocyte cells;

$\mathrm{SEM}=$ standard error mean

a,b.c : means in the same column and effect bearing different superscripts are significantly different $(\mathrm{P} \leq 0.05)$.

$\mathrm{NS}=$ non-significant $; *=\mathrm{P} \leq 0.05 ; * *=\mathrm{P} \leq 0.01$ 
L- carnitine, Ducks, Productive And Reproductive Performance, Season.

Table 7: Effect of season and dietary L-carnitine supplementation on serum constituents for Domyati ducks at 38 wks of age

\begin{tabular}{|c|c|c|c|c|c|c|c|}
\hline \multirow{2}{*}{\multicolumn{3}{|c|}{$\begin{array}{l}\text { Main effect } \\
\text { Season effect }(\mathbf{S})\end{array}$}} & $\begin{array}{c}\text { Total } \\
\text { protein } \\
(\mathrm{g} / \mathrm{dl})\end{array}$ & $\begin{array}{c}\text { Triglycerides } \\
(\mathrm{mg} / \mathrm{dl})\end{array}$ & $\begin{array}{c}\text { Total } \\
\text { cholesterol } \\
(\mathrm{mg} / \mathrm{dl})\end{array}$ & $\begin{array}{c}\text { ALT } \\
(\mathrm{U} / \mathrm{dl})\end{array}$ & $\begin{array}{c}\text { AST } \\
(\mathrm{U} / \mathrm{dl})\end{array}$ \\
\hline & & & & & & & \\
\hline \multicolumn{3}{|c|}{ Winter } & 6.61 & $334.35^{b}$ & $115.87^{\mathbf{b}}$ & $23.24^{\mathbf{b}}$ & $25.52^{b}$ \\
\hline \multicolumn{3}{|c|}{ Summer } & 6.19 & $492.33^{a}$ & $138.81^{\mathbf{a}}$ & $25.08^{a}$ & $29.07^{\mathrm{a}}$ \\
\hline \multicolumn{3}{|c|}{ Pooled SEM } & 0.10 & 14.60 & 4.56 & 0.58 & 0.96 \\
\hline \multicolumn{3}{|c|}{ Significance } & NS & $* *$ & $* *$ & $*$ & $*$ \\
\hline \multicolumn{8}{|c|}{ L-carnitine effect (LC, mg/kg) } \\
\hline \multicolumn{3}{|c|}{$\mathbf{0 . 0}$} & 6.20 & 446.93 & $164.95^{\mathrm{a}}$ & $26.78^{a}$ & $30.73^{\mathrm{a}}$ \\
\hline \multicolumn{3}{|c|}{150} & 6.38 & 428.58 & $134.67^{b}$ & $24.45^{b}$ & $27.28^{\mathbf{b}}$ \\
\hline \multicolumn{3}{|c|}{300} & 6.55 & 386.12 & $111.09^{b}$ & $23.20^{\mathbf{b}}$ & $25.60^{b}$ \\
\hline \multicolumn{3}{|c|}{450} & 6.44 & 397.44 & $113.49^{b}$ & $24.00^{b}$ & $26.27^{\mathrm{b}}$ \\
\hline \multicolumn{3}{|c|}{600} & 6.41 & 407.63 & $112.50^{\mathbf{b}}$ & $22.38^{\mathbf{b}}$ & $26.59^{b}$ \\
\hline \multicolumn{3}{|c|}{ Pooled SEM } & 0.16 & 23.09 & 7.21 & 0.91 & 1.52 \\
\hline \multicolumn{3}{|c|}{ Significance } & NS & NS & $* *$ & $*$ & $*$ \\
\hline \multirow{11}{*}{ 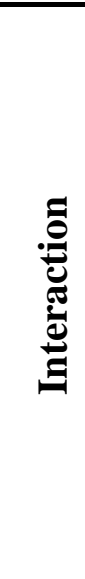 } & S. & $\mathbf{L C}$ & & & & & \\
\hline & \multirow{5}{*}{ 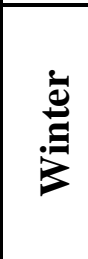 } & 0.0 & 6.65 & 353.86 & $165.83^{\mathrm{a}}$ & 25.55 & 29.45 \\
\hline & & 150 & 6.58 & 342.17 & $122.50^{\mathbf{a b}}$ & 22.90 & 25.55 \\
\hline & & 300 & 6.70 & 302.25 & $98.50^{\mathbf{b}}$ & 22.50 & 24.70 \\
\hline & & 450 & 6.63 & 334.88 & $97.50^{b}$ & 23.50 & 23.03 \\
\hline & & 600 & 6.48 & 338.58 & $95.00^{\mathbf{b}}$ & 21.75 & 24.85 \\
\hline & \multirow{5}{*}{$\underset{\Xi}{\grave{\Xi}}$} & 0.0 & 5.75 & 540.00 & $164.07^{\mathrm{a}}$ & 28.00 & 32.00 \\
\hline & & 150 & 6.18 & 515.00 & $146.84^{\mathrm{a}}$ & 26.00 & 29.00 \\
\hline & & 300 & 6.39 & 470.00 & $123.68^{\mathbf{a b}}$ & 23.90 & 26.50 \\
\hline & & 450 & 6.26 & 460.00 & $129.47^{\mathbf{a b}}$ & 24.50 & 29.50 \\
\hline & & 600 & 6.34 & 476.67 & $130.00^{\mathbf{a b}}$ & 23.00 & 28.33 \\
\hline \multicolumn{3}{|c|}{ Pooled SEM } & 0.23 & 32.65 & 10.20 & 1.29 & 2.14 \\
\hline \multicolumn{3}{|c|}{ Significance } & NS & NS & $*$ & NS & $\mathbf{N S}$ \\
\hline
\end{tabular}

a,b : means in the same column and effect bearing different superscripts are significantly different $(\mathrm{P} \leq 0.05)$.

$\mathrm{SEM}=$ standard error mean; $\mathrm{NS}=$ non-significant $; *=\mathrm{P} \leq 0.05 ; * *=\mathrm{P} \leq 0.01$ 
Table 8: Effect of season and dietary L-carnitine supplementation on nutrients digestibility coefficient (\%) for Domyati ducks.

\begin{tabular}{|c|c|c|c|c|c|c|c|c|c|c|c|}
\hline \multicolumn{3}{|c|}{ Main effect } & DM & $\mathbf{O M}$ & $\mathbf{C P}$ & $\mathbf{E E}$ & $\mathbf{C F}$ & NFE & Ash-ret. & TDN & ME (kcal/kg) \\
\hline \multicolumn{12}{|c|}{ Season effect $(\mathbf{S})$} \\
\hline \multirow{2}{*}{\multicolumn{3}{|c|}{$\begin{array}{c}\text { Winter } \\
\text { Summer }\end{array}$}} & $88.12^{\mathrm{a}}$ & $90.62^{a}$ & $94.30^{\mathrm{a}}$ & $92.87^{\mathrm{a}}$ & $50.86^{\mathrm{a}}$ & 91.70 & $69.13^{\mathrm{a}}$ & $69.68^{\mathrm{a}}$ & $2918.08^{\mathrm{a}}$ \\
\hline & & & $86.60^{\mathrm{b}}$ & $88.77^{\mathrm{b}}$ & $91.13^{b}$ & $78.47^{\mathbf{b}}$ & $33.45^{b}$ & 91.59 & $62.36^{\mathrm{b}}$ & $68.18^{b}$ & $2855.50^{\mathbf{b}}$ \\
\hline \multicolumn{3}{|c|}{ Pooled SEM } & 0.24 & 0.34 & 0.22 & 0.70 & 2.09 & 0.29 & 1.28 & 0.31 & 12.85 \\
\hline \multicolumn{3}{|c|}{ Significance } & $*$ & $* *$ & $* *$ & $* *$ & $* *$ & NS & $* *$ & $* *$ & $* *$ \\
\hline \multicolumn{12}{|c|}{ L-carnitine effect $(\mathrm{LC}, \mathrm{mg} / \mathrm{kg})$} \\
\hline \multicolumn{3}{|c|}{0.0} & 86.77 & $88.51^{\mathrm{c}}$ & $90.35^{b}$ & 84.733 & 37.517 & $90.95^{b}$ & $60.62^{b}$ & 68.28 & 2859.40 \\
\hline \multicolumn{3}{|c|}{150} & 86.90 & $88.78^{\text {bc }}$ & $91.30^{\mathrm{b}}$ & 85.132 & 39.046 & $90.95^{\mathrm{b}}$ & $64.37^{\mathrm{ab}}$ & 68.40 & 2864.67 \\
\hline \multicolumn{3}{|c|}{300} & 88.00 & $90.34^{\text {ab }}$ & $93.52^{\mathrm{a}}$ & 86.187 & 47.047 & $92.04^{\mathrm{a}}$ & $67.74^{\mathrm{a}}$ & 69.50 & 2910.71 \\
\hline \multicolumn{3}{|c|}{450} & 87.62 & $89.99^{\text {ab }}$ & $94.16^{\mathrm{a}}$ & 86.873 & 46.627 & $91.38^{\text {ab }}$ & $66.90^{\mathrm{a}}$ & 69.12 & 2894.60 \\
\hline \multicolumn{3}{|c|}{600} & 87.53 & $90.85^{\mathrm{a}}$ & $94.25^{\mathrm{a}}$ & 85.417 & 40.534 & $92.92^{\mathrm{a}}$ & $69.10^{\mathrm{a}}$ & 69.36 & 2904.57 \\
\hline \multicolumn{3}{|c|}{ Pooled SEM } & 0.38 & 0.53 & 0.35 & 1.11 & 3.31 & 0.46 & 2.03 & 0.49 & 20.32 \\
\hline \multicolumn{3}{|c|}{ Significance } & NS & $*$ & $*$ & $\mathbf{N S}$ & NS & $*$ & $*$ & NS & NS \\
\hline \multirow{11}{*}{ 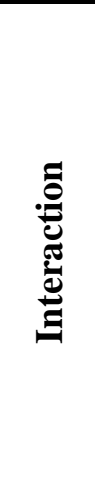 } & S. & $\mathbf{L C}$ & & & & & & & & & \\
\hline & \multirow{5}{*}{ 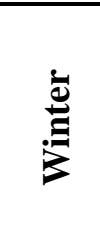 } & 0.0 & 87.37 & 89.35 & $92.80^{\text {ab }}$ & 93.01 & 47.12 & $90.56^{\mathrm{bc}}$ & 64.42 & 68.93 & 2886.95 \\
\hline & & 150 & 87.29 & 90.22 & $92.19^{\mathbf{a b}}$ & 93.64 & 44.99 & $91.98^{\mathbf{a b}}$ & 66.91 & 69.86 & 2925.53 \\
\hline & & 300 & 89.74 & 91.99 & $96.00^{\mathrm{a}}$ & 93.09 & 55.18 & $92.89^{\mathrm{a}}$ & 74.29 & 70.82 & 2966.09 \\
\hline & & 450 & 87.79 & 90.40 & $95.51^{\mathrm{a}}$ & 91.89 & 56.56 & $90.83^{\text {bc }}$ & 70.34 & 69.47 & 2909.36 \\
\hline & & 600 & 88.41 & 91.14 & $95.01^{\mathrm{a}}$ & 92.70 & 50.47 & $92.25^{\mathrm{a}}$ & 69.72 & 69.31 & 2902.48 \\
\hline & \multirow{5}{*}{$\begin{array}{l}\dot{\bar{\Xi}} \\
\dot{\Xi} \\
\bar{\Xi}\end{array}$} & 0.0 & 86.17 & 87.68 & $87.91^{\mathrm{c}}$ & 76.46 & 27.92 & $91.34^{\mathrm{ab}}$ & 56.83 & 67.62 & 2831.85 \\
\hline & & 150 & 86.51 & 87.34 & $90.42^{b c}$ & 76.62 & 33.11 & $89.93^{c}$ & 61.83 & 66.95 & 2803.81 \\
\hline & & 300 & 86.26 & 88.69 & $91.04^{b}$ & 79.28 & 38.92 & $91.18^{a b}$ & 61.19 & 68.18 & 2855.34 \\
\hline & & 450 & 87.44 & 89.58 & $92.80^{\text {ab }}$ & 81.86 & 36.70 & $91.93^{\text {ab }}$ & 63.46 & 68.76 & 2879.84 \\
\hline & & 600 & 86.64 & 90.57 & $93.48^{\text {ab }}$ & 78.14 & 30.59 & $93.59^{\mathrm{a}}$ & 68.49 & 69.41 & 2906.67 \\
\hline \multicolumn{3}{|c|}{ Pooled SEM } & 0.54 & 0.75 & 0.50 & 1.57 & 4.68 & 0.65 & 2.87 & 0.69 & 28.74 \\
\hline \multicolumn{3}{|c|}{ Significance } & NS & NS & $*$ & $\mathbf{N S}$ & NS & $*$ & NS & NS & NS \\
\hline
\end{tabular}

DM: dry matter; OM: organic matter; CP: crude protein; EE: ether extract; CF: crude fiber; NFE: nitrogen free extract; TDN: total digestibility of nutrients; ME: metabolizable energy; $\mathrm{NS}=$ non-significant; $*=\mathrm{P} \leq 0.05 ; * *=\mathrm{P} \leq 0.01$

a,b.c :means in the same column bearing different superscripts are significantly different $(\mathrm{P} \leq 0.05)$. SEM $=$ standard error mean 
Table 9: Effect of season and dietary L-carnitine supplementation on economic efficiency (EE) for Domyati ducks.

\begin{tabular}{|c|c|c|c|c|c|c|c|c|}
\hline \multirow{2}{*}{\multicolumn{3}{|c|}{$\begin{array}{l}\text { Main effect } \\
\text { Season effect (S) } \\
\end{array}$}} & $\begin{array}{c}\text { Total } \\
\text { Feed cost } \\
(\text { LE) }\end{array}$ & $\begin{array}{c}\text { Total } \\
\text { LC cost } \\
(\mathbf{L E})\end{array}$ & $\begin{array}{l}\text { Total } \\
\text { cost } \\
(\text { LE) }\end{array}$ & $\begin{array}{c}\text { Total } \\
\text { return } \\
(\mathrm{LE})\end{array}$ & $\begin{array}{l}\text { Net } \\
\text { return } \\
(\text { LE) }\end{array}$ & $\mathbf{E E}$ \\
\hline & & & & & & & & \\
\hline \multirow{2}{*}{\multicolumn{3}{|c|}{$\begin{array}{c}\text { Winter } \\
\text { Summer } \\
\end{array}$}} & $63.08^{\mathrm{a}}$ & $1.23^{\mathrm{a}}$ & $64.31^{\mathrm{a}}$ & $79.15^{a}$ & $14.84^{b}$ & $0.232^{\mathbf{b}}$ \\
\hline & & & $54.82^{b}$ & $1.09^{b}$ & $55.92^{\mathbf{b}}$ & $74.05^{b}$ & $18.13^{\mathbf{a}}$ & $0.324^{\mathrm{a}}$ \\
\hline \multicolumn{3}{|c|}{ Pooled SEM } & 0.27 & 0.01 & 0.27 & 0.52 & 0.64 & 0.01 \\
\hline \multicolumn{3}{|c|}{ Significance } & $* *$ & $* *$ & $* *$ & $* *$ & $* *$ & $* *$ \\
\hline \multicolumn{9}{|c|}{ L-carnitine effect (LC, mg/kg) } \\
\hline \multicolumn{3}{|c|}{0.0} & $60.09^{\mathrm{a}}$ & $0.00^{\mathrm{e}}$ & 60.09 & $71.69^{\mathbf{b}}$ & $11.60^{\mathbf{b}}$ & $0.202^{\mathbf{b}}$ \\
\hline \multicolumn{3}{|c|}{150} & $59.17^{\mathbf{a b}}$ & $0.59^{\mathrm{d}}$ & 59.76 & $77.85^{\mathrm{a}}$ & $18.10^{\mathrm{a}}$ & $0.306^{\mathrm{a}}$ \\
\hline \multicolumn{3}{|c|}{300} & $58.96^{\mathbf{a b}}$ & $1.17^{\mathrm{c}}$ & 60.13 & $78.91^{\mathbf{a}}$ & $18.78^{\mathrm{a}}$ & $0.314^{\mathbf{a}}$ \\
\hline \multicolumn{3}{|c|}{450} & $58.12^{\mathbf{b}}$ & $1.73^{\mathbf{b}}$ & 59.85 & $77.50^{\mathrm{a}}$ & $17.65^{\mathrm{a}}$ & $0.298^{\mathbf{a}}$ \\
\hline \multicolumn{3}{|c|}{600} & $58.42^{\mathbf{b}}$ & $2.32^{\mathrm{a}}$ & 60.74 & $77.04^{\mathbf{a}}$ & $16.30^{\mathbf{a}}$ & $0.271^{\mathrm{a}}$ \\
\hline \multicolumn{3}{|c|}{ Pooled SEM } & 0.42 & 0.01 & 0.43 & 0.82 & 1.01 & 0.02 \\
\hline \multicolumn{3}{|c|}{ Significance } & $* *$ & $* *$ & NS & $* *$ & $* *$ & $* *$ \\
\hline \multirow{11}{*}{ } & S. & $\mathbf{L C}$ & & & & & & \\
\hline & \multirow{5}{*}{ 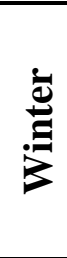 } & 0.0 & $66.26^{\mathrm{a}}$ & $0.00^{\mathrm{e}}$ & $66.26^{\mathrm{a}}$ & 73.71 & 7.45 & $0.112^{\mathrm{d}}$ \\
\hline & & 150 & $63.75^{\mathbf{a b}}$ & $0.63^{d}$ & $64.39^{\mathbf{a b}}$ & 82.08 & 17.70 & $0.275^{\mathrm{bc}}$ \\
\hline & & 300 & $61.61^{b}$ & $1.22^{\mathrm{c}}$ & $62.83^{b}$ & 80.46 & 17.63 & $0.282^{\mathrm{bc}}$ \\
\hline & & 450 & $61.61^{b}$ & $1.84^{\mathbf{b}}$ & $63.44^{\text {ab }}$ & 79.70 & 16.26 & $0.257^{\mathrm{c}}$ \\
\hline & & 600 & $62.17^{b}$ & $2.47^{\mathrm{a}}$ & $64.64^{\mathbf{a b}}$ & 79.80 & 15.16 & $0.235^{\mathrm{c}}$ \\
\hline & \multirow{5}{*}{ ఏ } & 0.0 & $53.93^{c}$ & $0.00^{\mathrm{e}}$ & $53.93^{d}$ & 69.68 & 15.75 & $0.292^{\mathrm{bc}}$ \\
\hline & & 150 & $54.58^{c}$ & $0.54^{d}$ & $55.12^{\text {cd }}$ & 73.62 & 18.50 & $0.336^{\mathrm{a}}$ \\
\hline & & 300 & $56.31^{\mathrm{c}}$ & $1.12^{\mathrm{c}}$ & $57.43^{\mathrm{c}}$ & 77.36 & 19.93 & $0.347^{\mathrm{a}}$ \\
\hline & & 450 & $54.64^{\mathrm{c}}$ & $1.63^{b}$ & $56.26^{\mathrm{c}}$ & 75.31 & 19.04 & $0.339^{\mathrm{a}}$ \\
\hline & & 600 & $54.67^{\mathrm{c}}$ & $2.17^{\mathrm{a}}$ & $56.84^{\mathrm{c}}$ & 74.28 & 17.44 & $0.307^{\mathbf{a b}}$ \\
\hline \multicolumn{3}{|c|}{ Pooled SEM } & 0.59 & 0.02 & 0.61 & 1.16 & 1.42 & 0.03 \\
\hline \multicolumn{3}{|c|}{ Significance } & $* *$ & $* *$ & $* *$ & $\mathrm{NS}$ & NS & $*$ \\
\hline
\end{tabular}

a,b,c,d :means in the same column $b$ and effect earing different superscripts are significantly different $(\mathrm{P} \leq 0.05)$.

$\mathrm{SEM}=$ standard error mean $; \mathrm{NS}=$ non-significant; $*=\mathrm{P} \leq 0.05 ; * *=\mathrm{P} \leq 0.01$ 


\section{REFERENCES}

Adabi, G.S.H.; R.G. Cooper; N. Ceylan and M. Corduk (2011). Lcarnitine and its functional effects in poultry nutrition. World's Poult. Sci. J., 67, 277-296.

Al- Hayani, W.K.H. (2012). The uses of different levels of L- carnitine for improve productive performance of Guinea Fowl. Ph. D. Dissertation. College of Agriculture, University of Baghdad.

Al-Daraji, H.J. and A.O. Tahir (2014a). Effect of L-carnitine on duck breeder fertility, hatchability and sex hormones. Res. Opin. Anim. Vet. Sci., 4(11): 608-613.

Al-Daraji, H.J. and A.O. Tahir (2014b). Effect of L-carnitine supplementation on drake semen quality. South African J. of Anim. Sci. vol, 44: 18-25

AL-Daraji, H.J. and A. O. Tahir (2013). Effect of dietary supplementation with L-canitine on productive performance of local ducks. Inter. J. of Agric. Sci., 3: 101110.

AOAC. (1995). Official Methods of Analysis. $16^{\text {th }}$ ed. Assoc. Off. Anal. Chem., Washington, DC.

Arenas, J.; J.C. Rubio and M.A. Martin (1998). Biological roles of L-carnitine in perinatal metabolism. Early Human Development, 53, 4350.

Awad, A.L. (2013). Field study on hatching traits of duck eggs under Egyptian environmental conditions. Egypt. Poult. Sci. J. Vol., 33: 849863.

Awad, A.L.; Kout-elkloub, M.E.M. and A.I.A. Ghonim (2011). Response of Domyati ducks to diets containing different levels of metabolizable energy and crude protein. 2- During laying period. Egypt Poult. Sci. J. 31: 77-95.

Baumgartner, M. (2003). Breeders perform better with L-carnitine. Int. Hatch. Pract., 17:4-15.

Behrouz, G.A.; H. Samie and R. Jahanian (2010). Effects of supplementary dietary L-carnitine on performance and egg quality of laying hens fed diets different in fat level. Italian J. of Anim. Sci., 9:1115

Bijlsma, R. and V. Loeschcke (2005). Environmental stress, adaptation and evolution: An overview. J. Evol. Biol., 18: 744-749.

Bonnet, S.; P. A. Geraert; M. Lessire; B. Carre; and G. Solange (1997). Effect of high ambient temperature on feed digestibility in broilers. Poult. Sci., 76:857-863.

Brillard, J.P. (2003). Practical aspects of fertility in poultry. World's Poult. Sci. J., 59: 441-446.

Cetin, N.; T. Bekyurek and E. Cetin (2009). Effect of sex, pregnancy and season on some haematological and biochemical blood values in Angora rabbits. Scand. J. Lab. Anim. Sci., 36 (2): 155-162.

Daşkıran, M.; A.G. Önol ; O. Cengiz ; O. Tatlı and M. San (2009). Effects of dietary methionine levels and Lcarnitine supplementation on performance and egg quality parameters of layers, J. Anim. Feed Sci., 18: 650-661

Deng, K.; C.W. Wong and J.V. Nolan (2006). Long-term effects of earlylife dietary L-carnitine on lymphoid organs and immune responses in leghorn- type chickens. J. Anim. Phys. Anim. Nutr., 90: 81-86.

Duncan, D.B. (1955).Multiple range and multiple F tests. Biometrics, 11:142.

Feed Composition Tables for Animals and Poultry Feedstuffs Used in 
Egypt (2001). Technical Bulletin No., 1, Central Lab. for Food and Feeds (CLFF) Ministry of Agric. Res. Cent. Egypt.

Harmeyer, J. and M. Baumgartner (1999). Effects of supplemental carnitine in feeds for laying hens and broilers. Pages 195-204 in Proc. 5th Conf. Schweineund Geflu gelernaehrung, Martin-Luther Universitaet, Halle-Wittenberg, Germany.

Jameel, Y.J. (2014). Effect of the content of fish oil, 1- carnitine (50 $\mathrm{mg} / \mathrm{kg}$ ) and their combination in diet on immune response and some blood parameters of broilers. Int. J. Sci. Nat. vol., 5: 501-504

Krishnan, S., B. S. Ramakrishna and H. J. Binder (1999). Stimulation of sodium chloride absorption from secreting rat colon by short-chain fatty acids. Diges. Dis. Sci. 44:19241930.

Ma, X.; Y. Lin ; H. Zhang ; W. Chen ; S. Wang ; D. Ruan and Z. Jiang (2014). Heat stress impairs the nutritional metabolism and reduces the productivity of egg-laying ducks. Anim. Rep. Sci., 145: 182190.

Macleod, M.G. (2004). Climatenutrition interactions in poultry. $1^{\text {rst }}$ Ann. Confr. , FVM., Moshtohor, September: 1-21.

Mujahid, A. (2010). Acute cold-induced thermogenesis in neonatal chicks (Gallus gallus). Comp. Biochem. Physiol. A Mol. Integr. Physiol. 156:34-41.

Mumma, J.O.; J.P. Thaxton ; V. Y. Thaxton and W.L. Dodson (2006). Physiological stress in laying hens. Poult. Sci., 85: 761-769.

Neuman, S.L.; T.L.Lin and P.Y. Hester (2002). The effect of dietary carnitine on semen traits of White Leghorn roosters. Poult. Sci., 81,
495-503.

Nofal. M. E.; H.R. Samak; Y. A. Mariey and R. M. Mahamud (2006). Production performance and serum constituents of aged Gimizah hens as affected by dietary supplementation with L-carntine. Egypt. Poult. Sci., 26:1269-1283.

Obidi, J.A.; B.I. Onyeanusi ; P.I. Rekwot; J.O. Ayo and T. Dzenda (2008). Seasonal variations in seminal characteristics of Shika brown breeder cocks. Inte. J. Poult. Sci., 7(12), 1219-1223.

Oguntunji, A.O. and A.E. Salako (2012): Effect of genotype and season on the productive performance of commercial Eggtype chickens in the derived savanna zone in Nigeria. Nigerian J. Anim. Prod., 39 (2), 4-13.

Oladele, S.B.; S. Ogundipc; J. O. Ayo and K. A. N. Esievo (2001). Eff ects of season and sex on packed cell volume, haemoglobin and total proteins of indigenous pigeons in Zaria, Northern Nigeria. Vet. Arhiv, vol., 71: 277-286.

Olawumi, S.O. (2015). The effect of seasonal variability on fertility and mortality rates of two strains of breeder cocks in the humid tropics. J. Anim. and Vet. Sci., 2: 43-46

Parizadian, B.; Y.J. Ahangari; M. Shams Shargh and A. Sardarzadeh (2011). Effects of different levels of 1-carnitine supplementation on egg quality and blood parameters of laying Japanese quail. Int. J. Poult. Sci., 10 (8): 621625

Peebles, E. D.; M. T. Kidd; C. D. McDaniel; J. P. Tanksley; H. M. Parker; A. Corzo, and J. C. Woodworth (2007). Effects of breeder hen age and dietary Lcarnitine on progeny 
embryogenesis. Br. Poult. Sci., 48:299-307

Ratriyanto A.; R. Mosenthin; E. Bauer and M. Eklund (2009). Metabolic osmoregulatory and nutritional functions of betaine in monogastric animals. Asian-Aust. J. Anim. Sci., 10:1461-1476.

Richter, V.G.; C. Schlumbohm; M. Boumgartner and W.I. Ochrimenko (1998). Studies of Lcarnitine effects in laying hens. Archiv-fur. Geflugelkunde, 62: 1-6.

Sarica, S.; M. Corduk; M. Suicmez ; F. Cedden; $M$. Yildirim and $K$. Kilinc (2007). The effects of dietary l-carnitine supplementation on semen traits, reproductive parameters, and testicular histology of Japanese quail breeders. J. Appl. Poult. Res., 16:178-186.

SAS (2004). SAS User's Guide: Statistics. Edition 9.1. SAS Institute Inc., Cary, NC.

Sato, M.; T. Tachibana and M. Furuse (2006). Heat production and lipid metabolism in broiler and layer chickens during embryonic development. Comparative Biochemistry and Physiology Part A: Molecular \& Integrative Physiology, 143: 382-388.
Simon, M.S. (2003). Reducing heat stress problem. World Poult.Sci. Vol., 19: 16-17.

Thiemel, J. and P. Jelínek (2004). The effect of carnitine on hatching rate and metabolic profile of blood in breeding layers. Czech J. Anim. Sci., 49, 517-523.

Tona, K.; O. Onagbesan; B. De Ketelaere; E. Decuypere and V. Bruggeman (2004). Effects of age of broiler breeders and egg storage on egg quality, hatchability, chick quality, chick weight, and post-hatch growth to forty-two days. J. Appl. Poult. Res., 13:10-18.

Vaz, F.M. and R. J. Wanders (2002): Carnitine biosynthesis in mammals. Biochem. J. 361: 417-429.

Yalcin, S.; A. Ergun; H. Erol; S. Yalcin, and B. Ozsoy (2005). Use of L-carnitine and humate in laying quail diets. Acta Vet. Hung., 53:361-370.

Zhai, W.; S.L. Neuman ; M.A. Latour and P.Y. Hester (2008). The effect of male and female supplementation of L-carnitine on reproductive traits of white Leghorns. Poult. Sci., 87:1171-1181. 


\section{الملخص العربي}

تأثير الموسم وإضافة إل-كارنيتين للعليقة على الأداء الانتاجى والتناسلى لسلالات البط المحلية عوض لطفي عوض، هاني نبيل فهيم ، ملاك منصور بشاره

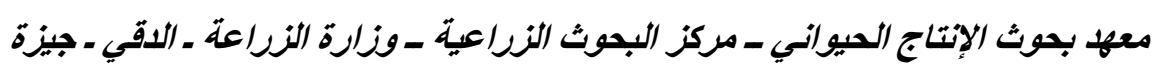

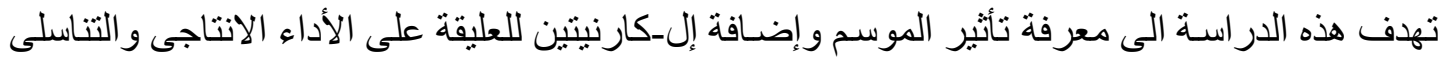

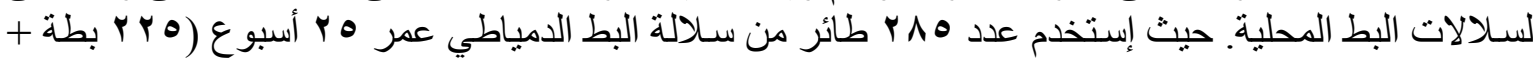

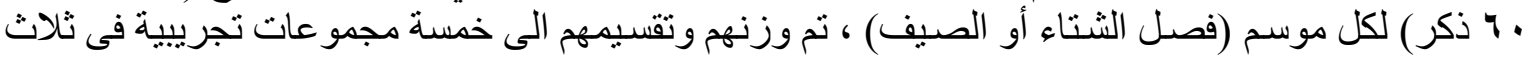

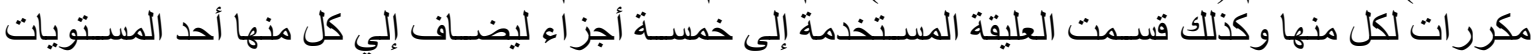

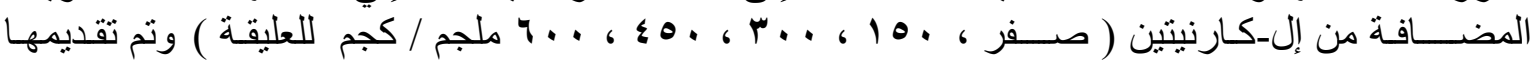

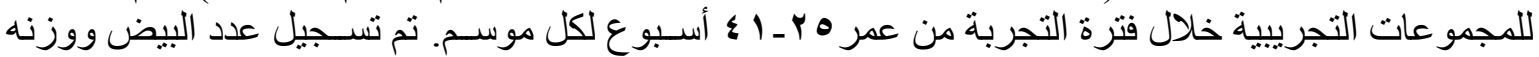

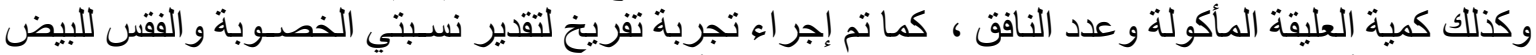

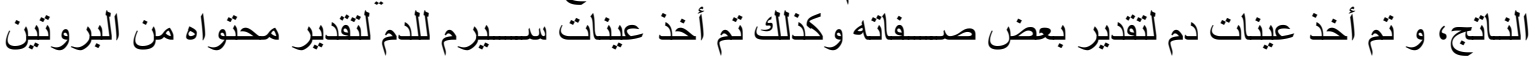

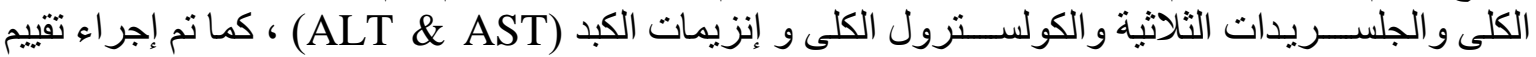

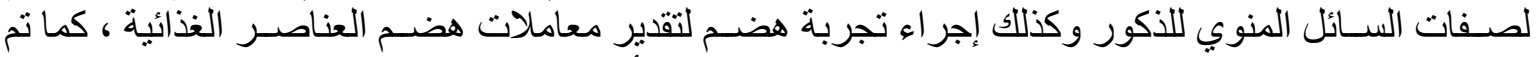

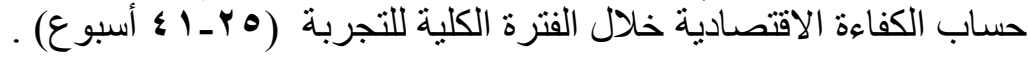
وتوضح النتائج ما يلي :-

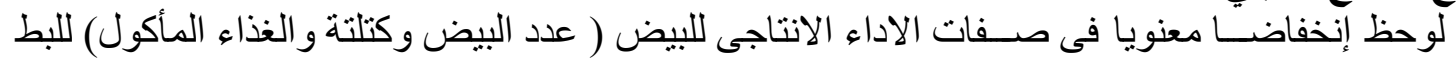

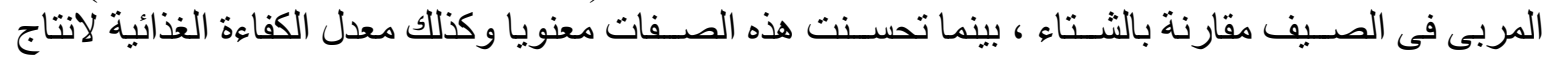

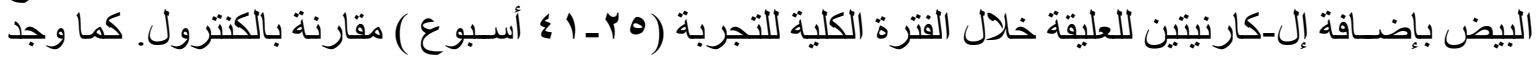

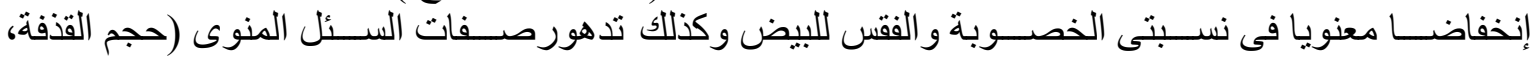

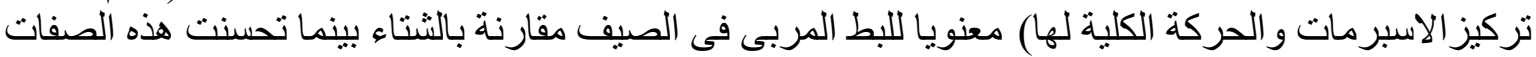

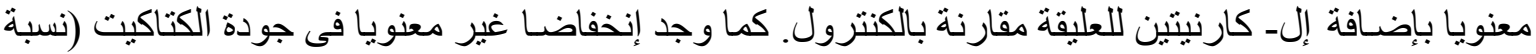

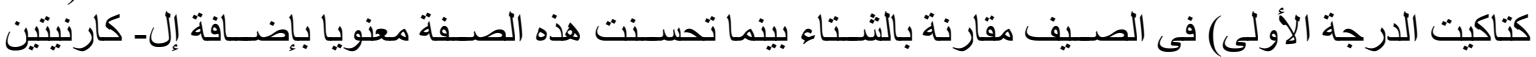

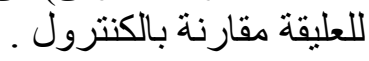

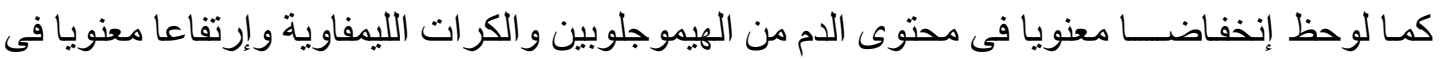

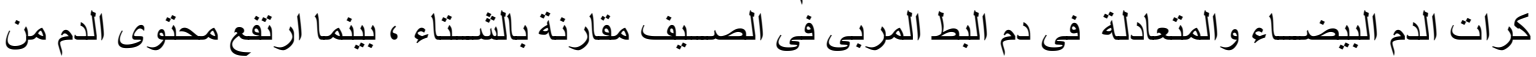

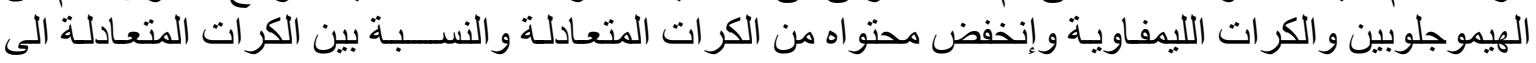

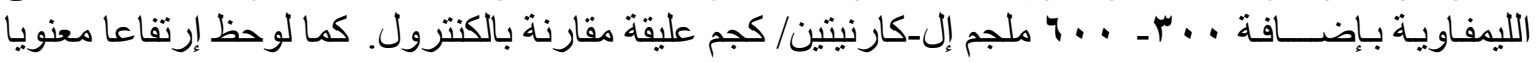

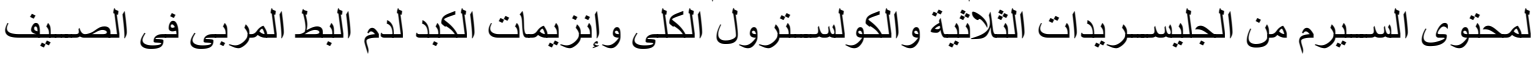

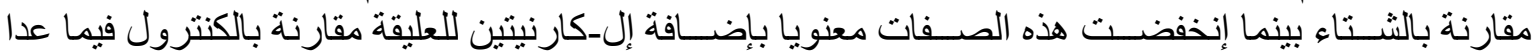

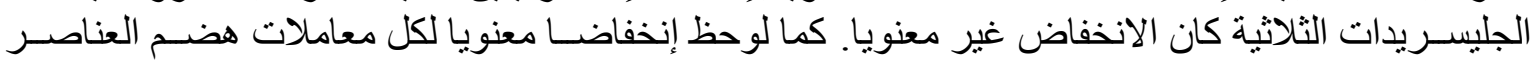

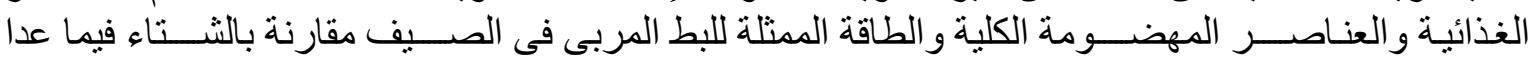

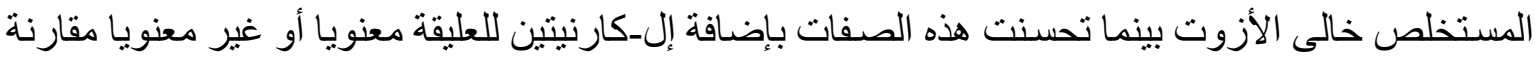

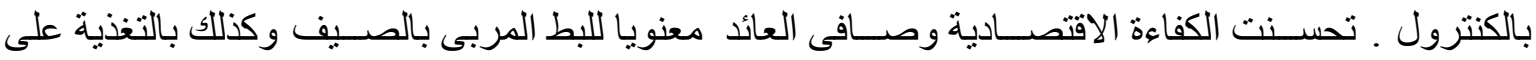

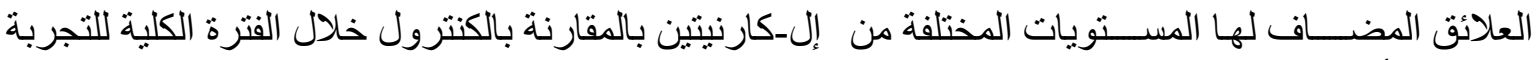

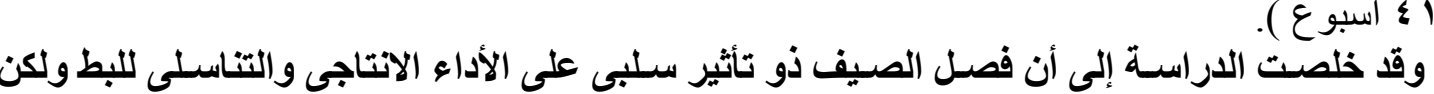

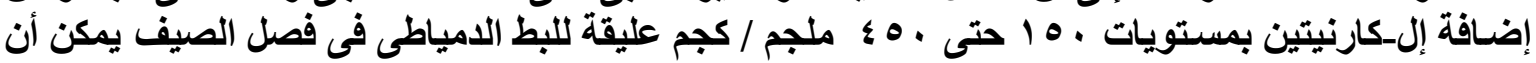

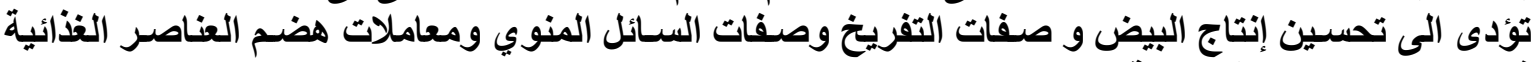
فضلا عن الكفاءة الاقتصادية. 